\title{
Mapping Relevant Parameters for Efficient Operation of Low-Temperature Heating Systems in Nordic Single-Family Dwellings
}

\author{
Adnan Ploskić ${ }^{1,2}$, Qian Wang ${ }^{1,3, *}$ and Sasan Sadrizadeh ${ }^{1,4} \mathbb{D}$ \\ 1 Division of Fluid and Climate Technology, School of Architecture and the Built Environment, \\ KTH Royal Institute of Technology, SE-100 44 Stockholm, Sweden; adnan.ploskic@byv.kth.se (A.P.); \\ ssad@kth.se (S.S.) \\ 2 Bravida Holding AB, Mikrofonvägen 28, 12637 Hägersten, Sweden \\ 3 Uponor AB, Hackstavägen 1, 72132 Västerås, Sweden \\ 4 Center for the Built Environment, Department of Architecture, University of California, Berkeley, \\ CA 94720, USA \\ * Correspondence: qianwang@kth.se; Tel.: +46-706881218
}

Received: 10 September 2018; Accepted: 15 October 2018; Published: 18 October 2018

\begin{abstract}
The aim of this study was to map the parameters that have the greatest impact on the environmental impact of heating systems usually used in Nordic single-family dwellings. The study focused on mapping the technical requirements for efficient operation of heating systems in a broader context. The results suggest that the ability of a heating system to be operated with a low-temperature water supply depends to a large extent on the heating demand of a building. It was shown that an increase in the water flow rate in hydronic circuits would significantly increase the thermal efficiency from analyzed heating systems. This increase would not increase the pumping power need, nor would it create noise problems in distribution network if the distribution pipes and thermostatic valves were properly selected. However, this increase in water flow rate improved the efficiency of considered closed-loop heat pump. It was further shown that the efficiency of the heat pump could be additionally improved by halving the energy needs for the domestic hot-water and circulators. The main conclusion from this study is that exergy usage, $\mathrm{CO}_{2}$ emission and thereby environmental impact are significantly lower for heating systems that are operated with small temperature drops.
\end{abstract}

Keywords: low-temperature heating; energy efficiency; $\mathrm{CO}_{2}$ emissions; heat pump; hydraulic losses; system analysis

\section{Introduction}

An increased awareness that resources are limited has obliged many countries to revise their energy policies, and to implement various measures to reduce energy use. This has also broadened interest of the engineering and research communities to take a deeper look at energy management, and to develop new methods for more efficient energy use. Such measures include the so-called '20-20-20 targets' that were agreed to by member states of the European Union in 2007 [1]. This action plan aims to achieve a $20 \%$ reduction of greenhouse gas emissions, a $20 \%$ increase in energy efficiency, and a 20\% increase of renewable energy use by 2020 compared with the 1990 levels. The initial targets were further tightened in 2015, requiring a reduction of greenhouse gas emissions by at least $40 \%$ and an increase of both energy efficiency and renewable energy use by at least 27\% by 2030 [1]. Yet these targets should only be viewed as a first step toward a low-carbon future. According to a report by the Intergovernmental Panel on Climate Change (IPCC) released in 2011, in order to limit Earth warming to a maximum of $2{ }^{\circ} \mathrm{C}$, the concentration of greenhouse gases in the atmosphere should not exceed 
$450 \mathrm{ppm} \mathrm{CO}_{2 \mathrm{eq}}[2,3]$. To achieve this, scientists believe that global $\mathrm{CO}_{2}$ emissions need to be reduced by 50 to $60 \%$ by 2050 . This requires a cut in industrialized countries by at least $80 \%$ compared with the 1990 level [4].

In order to meet these challenges, it is essential to invest in improvements in all sectors, including the building sector. European Commission has already launched the actions to accelerate the transformations to Net Zero Energy Buildings in order to meet these challenges [5,6]. The building sector currently accounts for a large proportion of the energy use and $\mathrm{CO}_{2}$ emissions in most countries. By 2015, residential buildings accounted for nearly $9 \%$ of $\mathrm{CO}_{2}$ emissions, and used $26 \%$ of the final energy in the European Union in 2012 [7,8]. Residential buildings also generated $6 \%$ of global $\mathrm{CO}_{2}$ emissions in 2010, and were responsible for 14\% of world-wide energy use in 2012 [9,10]. Therefore, by increasing the energy efficiency of buildings, the $\mathrm{CO}_{2}$ emissions caused by building services would correspondingly decrease. In order to achieve this, today's engineering community suggests that:

The thermal insulation and air tightness of building envelope should be improved.

The thermal efficiency of existing space heating appliances should be enhanced.

The use of renewable fuels in district heating, domestic heat pumps, condensing boilers should be increased, while at the same time improving the efficiency of these systems.

Unfortunately, current research activities commonly focus on exploring the potential of each of the above-mentioned measures independently. The result of such an approach is that the knowledge acquired is often fragmented, which limits operating engineers and decision-makers from getting a holistic view on how these three saving measures interact and affect each other. This limitation may limit and prolong the implementation of the necessary improvements in the building sector, and thus should be addressed in more detail and holistically than before. Consequently, the aims of the present study are:

To demonstrate the impact of building insulation on the operational mode of space heating systems. To demonstrate the potential of combining efficient space heating systems with a closed-loop heat pump.

To thoroughly investigate the hydraulic pressure losses and pumping power need in heating systems operated with high water flow rates.

0 To rate the influence of an increased water flow on exergy use and noise levels in the heating systems, and its impact on the efficiency of a closed-loop heat pump and $\mathrm{CO}_{2}$ emission from a single-family dwelling.

In other words, to demonstrate the joint potential of all the aforementioned energy saving measures and to map which parameters mostly affect the ability of a heating system to be operated with water supply temperature lower than $45^{\circ} \mathrm{C}$. Before we begin with the evaluation of the technical requirements, a short retrospective of development of hydronic heating systems in European countries is given in the two following sections.

\subsection{A Short Retrospective about Development of Hydronic Systems in Europe}

The process of switching from what were then considered high-temperature heating system with supply/return temperatures of $130^{\circ} \mathrm{C} / 60^{\circ} \mathrm{C}$ and $120^{\circ} \mathrm{C} / 100^{\circ} \mathrm{C}$ to then considered a low-temperature system $\left(90^{\circ} \mathrm{C} / 70^{\circ} \mathrm{C}\right)$ started in Europe in the middle of the twentieth century [11,12]. As heating demands of European buildings have constantly decreased since the 1950 s, the old $90{ }^{\circ} \mathrm{C} / 70{ }^{\circ} \mathrm{C}$ system was replaced by a new $75^{\circ} \mathrm{C} / 65^{\circ} \mathrm{C}$ low-temperature system in 1997 [13].

In Scandinavian countries, however, water temperatures used in hydronic systems were already lower than $75^{\circ} \mathrm{C} / 65^{\circ} \mathrm{C}$ by that time. In Denmark the supply and return temperatures in dwellings heated by natural gas boilers were limited to $62.5^{\circ} \mathrm{C}$ and $47.5{ }^{\circ} \mathrm{C}$, respectively, by 1995 [14]. For buildings served by district heating, the design supply/return temperatures at peak heating 
loads were limited to $70{ }^{\circ} \mathrm{C} / 40^{\circ} \mathrm{C}$ by that time. According to same building code, the water supply temperature cannot exceed $55^{\circ} \mathrm{C}$ in dwellings served by heat pumps [15].

Also, in Sweden in 1984 , a new regulation come into force, and old $80^{\circ} \mathrm{C} / 60^{\circ} \mathrm{C}$ high-temperature system was replaced by new $55{ }^{\circ} \mathrm{C} / 45{ }^{\circ} \mathrm{C}$ low-temperature system [16]. This new regulation at that time applies to newly built and renovated buildings only, and was still used as a design guide line in 2018. However, high-temperature water supply of $80^{\circ} \mathrm{C}$ (that is, $80^{\circ} \mathrm{C} / 40{ }^{\circ} \mathrm{C}$ and $80{ }^{\circ} \mathrm{C} / 30{ }^{\circ} \mathrm{C}$ systems) continued to be used in a number of existing Swedish apartment buildings even after 1984 [17]. Fahlén [18], in 2003, proposed to classify the 'new' $55^{\circ} \mathrm{C} / 45^{\circ} \mathrm{C}$ system as a medium-temperature system, as this heating system have already been Swedish standard for more than two decades by that time. According to his suggestion, hydronic heating systems should be classified as follows:

High-temperature systems for supply temperatures higher than $55^{\circ} \mathrm{C}$.

Medium-temperature systems for supply temperatures between $45{ }^{\circ} \mathrm{C}$ and $55^{\circ} \mathrm{C}$.

Low-temperature systems for supply temperatures less than $45^{\circ} \mathrm{C}$.

A somewhat more detailed classification of hydronic systems according to their operational temperatures have already been proposed three years earlier by a Dutch research team [19] and Ovchinnikov et al. [20] in 2016. The original classification suggested by Boerstra et al. [19] in 2000 is given in Table 1.

Table 1. Classification of hydronic heating systems according to Boerstra et al. [19].

\begin{tabular}{lccc}
\hline & Supply & Return & Temperature Drop \\
\hline Hydronic Heating System & ${ }^{\circ} \mathbf{C}$ & ${ }^{\circ} \mathbf{C}$ & ${ }^{\circ} \mathbf{C}$ \\
\hline High-temperature & 90 & 70 & 20 \\
Medium-temperature & 55 & 40 to 35 & 15 to 20 \\
Low-temperature & 45 & 35 to 25 & 10 to 20 \\
Very low-temperature & 35 & 25 & 10 \\
\hline
\end{tabular}

\subsection{Reflection on Current Classification of Hydronic Systems}

It should be noted that the return temperatures presented in Table 1 are a result of certain design traditions, regulations and operational conditions of a heating system. Therefore, Table 2 shows the temperature drops with the corresponding water flow rates usually used in current radiator systems. As seen, at a constant heat output, a high water flow rate generates a small temperature drop over the system and vice versa. According to Table 2, in order to keep constant heat output, water flow rate through a radiator must be increased by nearly 5 times if the supply water temperature is to be reduced from $75^{\circ} \mathrm{C}$ to $45^{\circ} \mathrm{C}$.

Table 2. Operating conditions of a conventional radiator consisting of two panels and two convector plates (type 22). Radiator dimensions: length $=1.2 \mathrm{~m}$, height $=0.6 \mathrm{~m}$.

\begin{tabular}{lccccc}
\hline & Supply & Return & Temperature Drop & Water Mass Flow & Heat Output \\
\hline Hydronic Heating System & ${ }^{\circ} \mathbf{C}$ & ${ }^{\circ} \mathbf{C}$ & ${ }^{\circ} \mathbf{C}$ & $\mathbf{~ k g} / \mathbf{h}$ & $\mathbf{W}$ \\
\hline High-temperature/low-flow & 75 & 23.9 & 51.1 & 9.91 & 580 \\
Medium-temperature/low-flow & 55 & 29.3 & 25.7 & 19.6 & 580 \\
Low-temperature/medium-flow & 45 & 34.6 & 10.4 & 48.6 & 580 \\
Low-temperature/high-flow & 41 & 37.8 & 3.20 & 158 & 580 \\
\hline
\end{tabular}

The data presented in Tables 1 and 2 show that (traditional) high-temperature systems are characterized by high supply water temperatures and large temperature drops. Due to this, the water flow rates in those systems are low, and this is why these systems are also commonly referred to as low-flow systems. On the other hand, low-temperature systems are associated with water supplies of lower temperatures, and with smaller temperature drops. The water flow rates 
in low-temperature systems are normally much higher than those in high-temperature systems. This is why low-temperature heating systems are usually also referred to as high-flow systems. This classification, however, is not fully correct and does not always apply. For example, in buildings with low-to-moderate heating demands, the heating systems can simultaneously operate in both the low-flow and the low-temperature mode. Therefore, the above-presented classification in Tables 1 and 2 should not be strictly applied, but should be viewed rather as a general guideline.

\subsection{General Characteristics of Low-Temperature Heating Systems}

Low-temperature heating systems have been a subject of extensive research during the last two past decades. The simulations and laboratory measurements have shown that this heating system is characterized by:

Higher pumping energy need compared to high-temperature systems [17].

- Higher heat output sensitivity due to variations in water flow rates compared to high-temperature systems [17].

Ability to provide better or the same level of thermal comfort as traditional high-temperature systems [20].

Higher share of thermal radiation (up to $50-70 \%$ ) compared to traditional systems, and high levels of perceived thermal comfort and indoor air quality [19,21,22].

○ Uniform heat distribution, low temperature stratification, low indoor air turbulence and low radiant temperature asymmetry inside the served rooms [23].

- Lower heat losses in distribution networks and more efficient use of heat pumps, low-grade waste and renewable heat compared to traditional high-temperature systems [24,25].

- Reduced primary energy use (up to $12 \%$ ) compared to traditional high-temperature systems [26,27].

It should be noted that previous studies seldom explicitly evaluated the importance of building heating demand and efficiency of entire system on ability of a heating system to be operated with low-temperature water supply. Therefore, one of the goals of this study was also to explore and rate the importance of these two important preconditions.

\section{Methodology}

The present study was divided into two parts. The first part aimed to demonstrate the impacts of outdoor climate, building insulation, and the efficiency of space heaters on the capacity of a heating system to be operated with a low-temperature water supply. The second part explored the effects of an increased water flow rate on the performance of the analyzed low-temperature heating systems.

\subsection{Space Heaters}

Three different space heaters were considered: conventional radiator, baseboard radiators and (under)floor heating. The floor heating acted as a reference, since this system is currently by far the most known and widely-used low-temperature heating system in single-family dwellings. All three systems used circulating hot-water for heat distribution.

In both the first and second part, the heat outputs from radiator systems were estimated according European Norm EN 442 [28,29], and according to EN 1264 for floor heating [30]. The estimated heat outputs were based on a constant room temperature of $20^{\circ} \mathrm{C}$, and fixed dimensions of space heaters. The conventional radiator was $1.2 \mathrm{~m}$ long and $0.5 \mathrm{~m}$ high, consisted of two panels and one convector plate (type 21) and had a heat emitting surface area of $4.8 \mathrm{~m}^{2}$. The length and height of the used baseboard radiators were set at $12 \mathrm{~m}$ and $0.15 \mathrm{~m}$, respectively, according current design practice [28]. The heat transferring surface area of this space heater was $2.0 \mathrm{~m}^{2}$. The heat emitting surface area of the floor heater was the same as the room floor area $\left(20 \mathrm{~m}^{2}\right)$. The distribution pipes in floor heating were arranged in straight lines with center-to-center distance of $0.3 \mathrm{~m}$, and the flooring (wooden parquet) above the pipes had a thermal resistance of $0.15\left(\mathrm{~m}^{2} \cdot{ }^{\circ} \mathrm{C}\right) / \mathrm{W}$. 


\subsection{Hydraulic Pressure and Power Losses in Analyzed Heating Systems}

The Darcy-Weisbach equation, Equation (1), was used for estimation of the pressure losses in distribution pipes for floor heating. Equation (1) was further combined with Equation (2) to estimate the power required by the circulation pump. The combined expression is shown by Equation (3), and presents the total pumping power need for water circulation in a heating system.

$$
\begin{gathered}
\Delta \mathrm{p}_{\text {circuit }}=\frac{8 \sum_{\mathrm{i}=1}^{\mathrm{n}} \mathrm{f}_{\mathrm{i}, \text { pipe }}\left(\mathrm{l}_{\mathrm{i}, \text { pipe }}+\mathrm{l}_{\mathrm{i}, \text { eq. }}\right)}{\rho \pi^{2} \mathrm{~d}_{\mathrm{i}}^{5}} \dot{\mathrm{m}}_{\mathrm{i}}^{2} \\
\mathrm{P}_{\text {pump }}=\frac{\Delta \mathrm{p} \dot{\mathrm{m}}}{\eta_{\text {pump }} \rho} \\
\mathrm{P}_{\text {pump, circuit }}=\frac{8 \sum_{\mathrm{i}=1}^{\mathrm{n}} \mathrm{f}_{\mathrm{i}, \text { pipe }}\left(\mathrm{l}_{\mathrm{i}, \text { pipe }}+\mathrm{l}_{\mathrm{i}, \text { eq. }}\right)}{\eta_{\text {pump }}(\pi \rho)^{2} \mathrm{~d}_{\mathrm{i}}^{5}} \dot{\mathrm{m}}_{\mathrm{i}}^{3}
\end{gathered}
$$

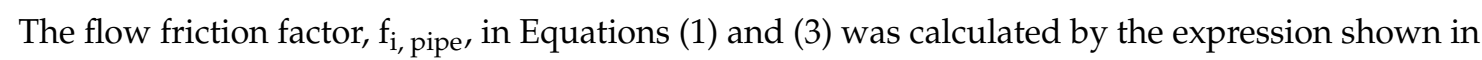
Equation (4). The expression was proposed by Churchill [31] in 1977, and is valid for the entire range of the Reynolds number $\left(\operatorname{Re}_{\mathrm{di}}>0\right)$ and relative pipe roughness $0 \leq \varepsilon / \mathrm{d}_{\mathrm{i}} \leq 0.05$. The expression is widely used in hydraulic engineering and consists of the following:

$$
\mathrm{f}_{\mathrm{i}, \text { pipe }}=8\left[\left(\frac{8}{\operatorname{Re}_{\mathrm{d}_{\mathrm{i}}}}\right)^{12}+\mathrm{A}^{-3 / 2}\right]^{1 / 12}
$$

where

$$
\mathrm{A}=\left(\frac{37530}{\operatorname{Re}_{\mathrm{d}_{\mathrm{i}}}}\right)^{16}+\left\{-2.457 \ln \left[\left(\frac{7}{\operatorname{Re}_{\mathrm{d}_{\mathrm{i}}}}\right)^{0.9}+0.27 \frac{\varepsilon}{\mathrm{d}_{\mathrm{i}}}\right]\right\}^{16}
$$

The pressure losses over the conventional radiator and associated thermostatic valve were estimated using Equations (5) and (6) [32], respectively.

$$
\begin{gathered}
\Delta \mathrm{p}_{\text {radiator }}=\zeta_{\text {radiator }} \frac{8}{\rho_{\text {water }}}\left(\frac{\dot{\mathrm{m}}_{\text {water }}}{\pi \mathrm{d}_{\text {inlet }}^{2}}\right)^{2} \\
\Delta \mathrm{p}_{\text {valve }}=\left(\frac{\dot{\mathrm{V}}_{\text {water }}}{\mathrm{K}_{\mathrm{v}}}\right)^{2} \frac{\rho_{\text {water }}}{\rho_{\text {ref. }}} \sqrt{\frac{\rho_{\text {water }}}{\rho_{\text {ref. }}}}=\left(\frac{\dot{\mathrm{M}}_{\text {water }}}{\rho_{\text {water }}}\right)^{2} \sqrt{\left(\frac{\rho_{\text {water }}}{\rho_{\text {ref. }}}\right)^{3}}
\end{gathered}
$$

\subsection{Exergy Use of Conventional Radiator}

In addition to estimation of pressure and pumping losses, the corresponding exergy use of the analyzed conventional radiator was also evaluated in order to explore the efficiency of the resource usage. Equation (7) was used to determine the rate of exergy use for radiator operation [33], whereas electrical exergy usage for associated pumping work was estimated by Equation (8) [34]. The total exergy use, shown by Equation (9), was then calculated by summing up the estimated values by Equations (7) and (8). As suggested in [35], the quality factor, $\mathrm{F}_{\mathrm{q} \text {, el., }}$ of electricity used for pump work was set at 0.97 . The reference temperature, $\mathrm{T}_{\text {ref., }}$ in Equation (7) were held constant at $271.45 \mathrm{~K}$ $\left(-1.7^{\circ} \mathrm{C}\right)$, which was considered as state of thermal equilibrium (dead state). The reason for this will be explained in Section 3.2.

$$
\frac{\dot{\text { Ex }} x_{\text {heat }}}{\dot{\mathrm{m}}_{\text {water }}}=\mathrm{c}_{\mathrm{p}, \text { water }}\left[\mathrm{T}_{\text {supp }}-\mathrm{T}_{\mathrm{rtn}}-\mathrm{T}_{\text {ref. }} \ln \left(\frac{\mathrm{T}_{\text {supp }}}{\mathrm{T}_{\mathrm{rtn}}}\right)\right]
$$




$$
\begin{gathered}
\frac{\dot{\mathrm{Ex}} \mathrm{x}_{\text {pump }}}{\dot{\mathrm{m}}_{\text {water }}}=\frac{\Delta \mathrm{p}_{\text {valve }}+\Delta \mathrm{p}_{\text {radiator }}}{\eta_{\text {pump }} \rho_{\text {water }}} \mathrm{F}_{\mathrm{q}, \text { el. }} \\
\frac{\dot{\mathrm{Ex}}}{\dot{\mathrm{m}}_{\text {radiator }}}=\frac{\dot{\mathrm{E}} \mathrm{x}_{\text {heat }}+\dot{\mathrm{E}} \mathrm{x}_{\text {pump }}}{\dot{\mathrm{m}}_{\text {water }}}
\end{gathered}
$$

\subsection{Ground-Source Heat Pump}

The seasonal electricity need of the used ground-source heat pump (GSHP) connected to the analyzed space heaters was estimated by the non-commercial code Vitocalc from 2010 [36]. The code was developed using an algorithm proposed by European Norm EN 14511, and was based on data from long-term measurements and real-life performances of various heat pump types collected by the Department of Energy Technology at KTH Royal Institute of Technology in Stockholm (Sweden). The code predicts the seasonal performance of heat pumps based on daily data about the following: the energy needs for space heating and domestic hot water (DHW), the outdoor, indoor and heat source temperature, the efficiency of the compressor, the type of condensation in the condenser, the supply and return temperatures of the evaporator and the connected heating system. For GSHPs, the effects of the depth of the borehole and the thermal conductivity of the ground are also taken into account.

In the first part of the study, besides the seasonal electricity need for the GSHP, the electricity requirements for the circulation pumps for the brine and heating circuits were also considered in order to estimate Heating Seasonal Performance Factor (HSPF) of the entire system. These were set at $288 \mathrm{kWh}(96 \mathrm{~W})$ for brine circulation pump and $317 \mathrm{kWh}(48 \mathrm{~W})$ for heating circuit pump [37], respectively. The inlet and outlet brine temperatures of evaporator were set at $0{ }^{\circ} \mathrm{C}$ and $-3{ }^{\circ} \mathrm{C}$, respectively, also in accordance with reported data from previous long-term field measurements [38].

\subsection{Reference Dwelling}

The analyzed space heaters together with the selected GSHP were assumed to serve a typical Scandinavian single-family dwelling built before 2000 . The considered dwelling had a total heated area of $150 \mathrm{~m}^{2}$, and was naturally ventilated. The dwelling had a total heating energy demand of $16.5 \mathrm{MWh}$ /year, of which 3.0 MWh was used DHW. This demand corresponded to an average energy use for space heating and DHW for a typical Scandinavian single-family dwelling built up to $2000[37,39,40]$

\section{Results}

In the following two sections, the effects of outdoor temperature, the building insulation, the choice of space heaters and the efficiency of GSHP on $\mathrm{CO}_{2}$ emission from a Scandinavian single-family dwelling are demonstrated. The mutual interdependence between these five parameters will be shown, and the importance of the cleanness of heat generation on $\mathrm{CO}_{2}$ emission will be explained. The effects of increased water flow rates in selected hydronic heating systems are also analyzed in detail. In order to get a better picture and insight of the interconnections between the parameters considered in this study, a flowchart of the mutual interdependencies is given in Figure 1. 


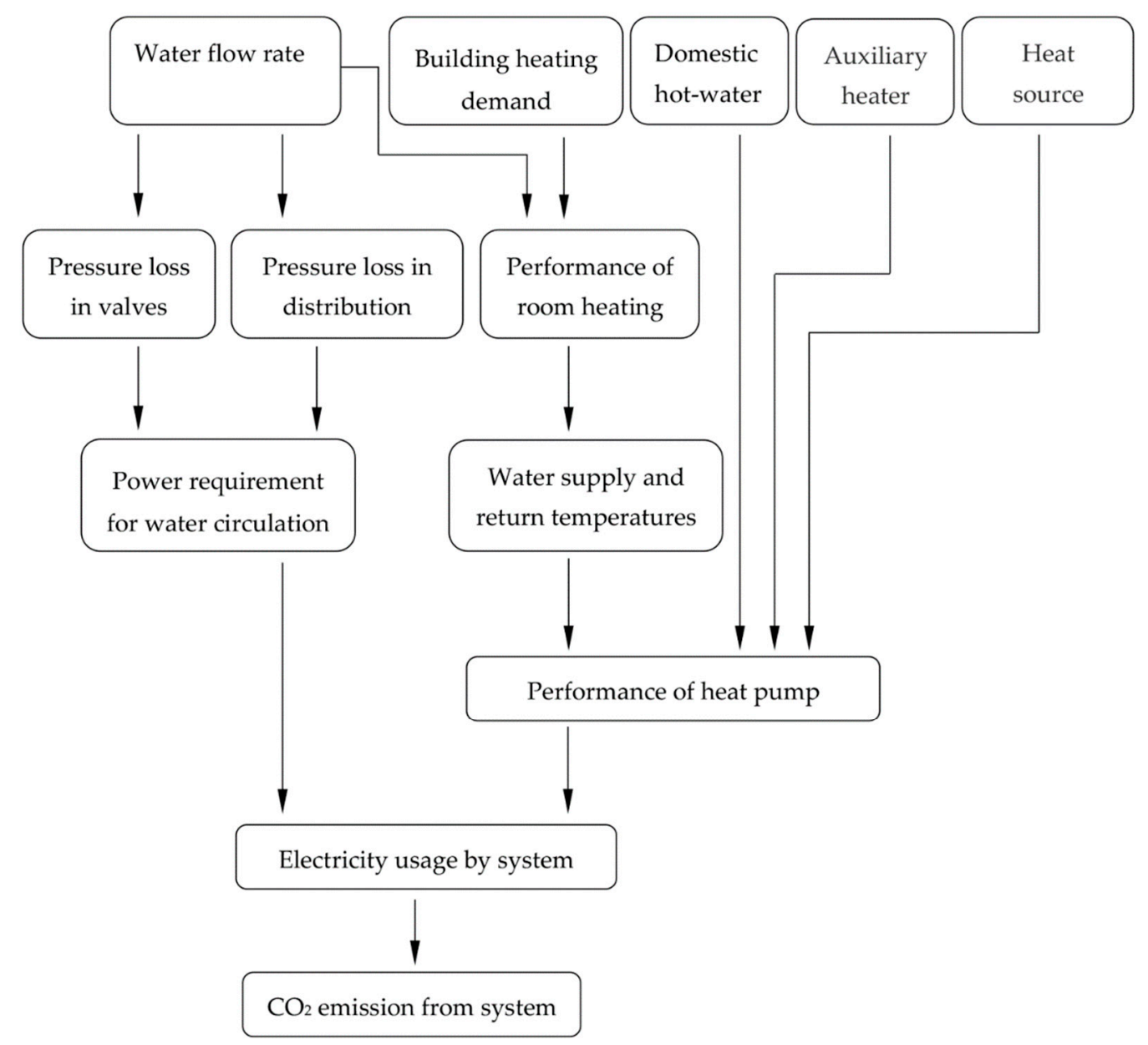

Figure 1. The flow chart of the interconnections between the parameters considered and their contribution to $\mathrm{CO}_{2}$ emission from the analyzed building.

\subsection{Effects of Building Insulation on the Operational Mode of Space Heaters}

Figure 2 illustrates how additional wall insulation decreases the annual heating energy need and the peak power heat load of a single-family dwelling [41]. The presented data is based on the indoor temperature of $21^{\circ} \mathrm{C}$ and the mean winter temperature of $1{ }^{\circ} \mathrm{C}$ and the design winter temperature of $-10{ }^{\circ} \mathrm{C}$. According to Figure 2, an increase of the mineral wool insulation from $30 \mathrm{~mm}$ to $300 \mathrm{~mm}$ would reduce the transmission heat losses by nearly seven times. This clearly illustrates the potential of such an energy-saving measure. The potential of this measure is also shown in Figure 3 which presents the improvement of energy efficiency in German building stock between 1969 and 2012 [42]. Figure 3 also shows the variation of heat output with excess (logarithmic mean temperature difference between a space heater and the room air) temperature for two radiator types.

Figure 3 indicates that the heat loss from an average German building in 1977 could be covered by a conventional radiator consisting of two panels and two convector plates (type 22) with $90{ }^{\circ} \mathrm{C} / 70{ }^{\circ} \mathrm{C}$ system. For same building built according to the German energy requirements in 2012, the very same radiator would covered the heat loss with a $45^{\circ} \mathrm{C} / 35^{\circ} \mathrm{C}$ system. This could be explained as follows: by adding more thermal insulation, the heat loss of the building would decrease; this in turn would require less active heat supply from the heating system, which could then be operated with water supply of lower temperature. However, the same result could be accomplished with high-temperature radiator system if a low water flow rate would be used, as shown in Table 2.

Figure 3 also illustrates the significance of the heat transferring area of radiators, especially if they are aimed to be operated with low-temperature water supplies. According to Figure 3, a radiator of type 22 needed to be operated with a $45{ }^{\circ} \mathrm{C} / 35^{\circ} \mathrm{C}$ system to cover a heat loss of $30 \mathrm{~W} / \mathrm{m}^{2}$ per 
floor area. By using a radiator of the same dimensions but without convector plates (type 20), the operational temperatures must be increased by $10^{\circ} \mathrm{C}$ (to $55^{\circ} \mathrm{C} / 45^{\circ} \mathrm{C}$ system) to cover the same loss. Later, it would be shown that this temperature increase would have a negative impact on the efficiency of a closed-loop heat pump.

In addition, Figure 3 shows that radiator heat output is strongly affected by the level of the supply temperature. The relative loss of heat output for supply temperatures lower than $50{ }^{\circ} \mathrm{C}$ is much more noticeable than for higher supply temperatures. This clearly indicates that present-day conventional radiators are not designed for efficient operation with low-temperature supplies.

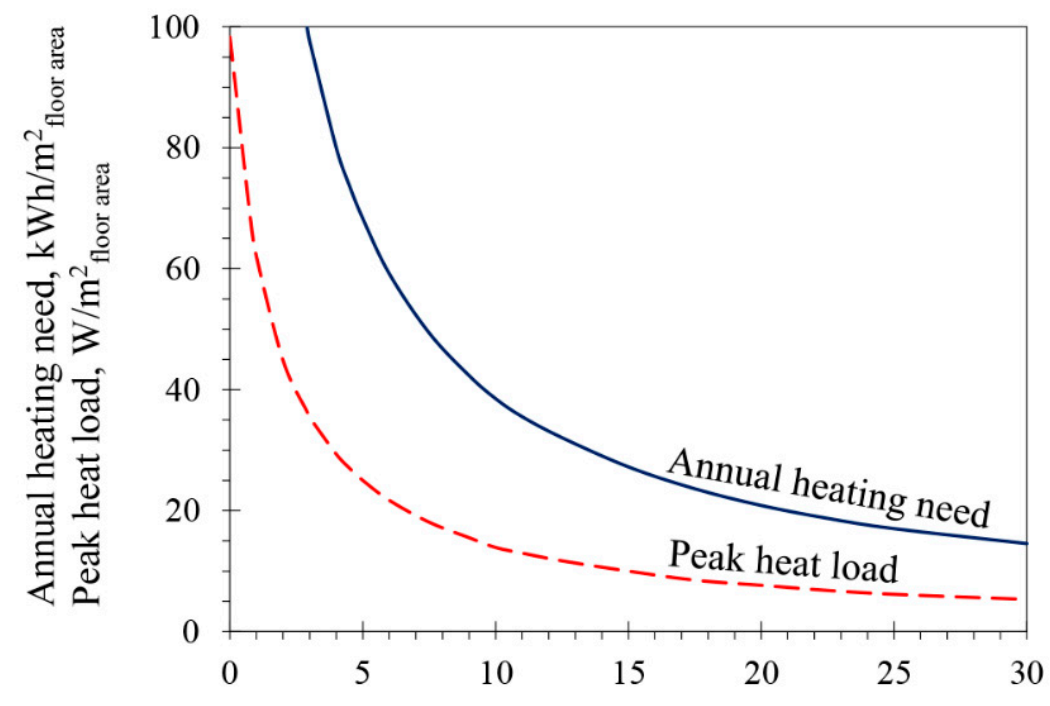

Additional insolation on existing $20 \mathrm{~cm}$ block wall, $\mathrm{cm}$

Figure 2. The decrease of annual heating energy need and peak heat power need per square meter heated floor area using increased mineral wool insulation [41].

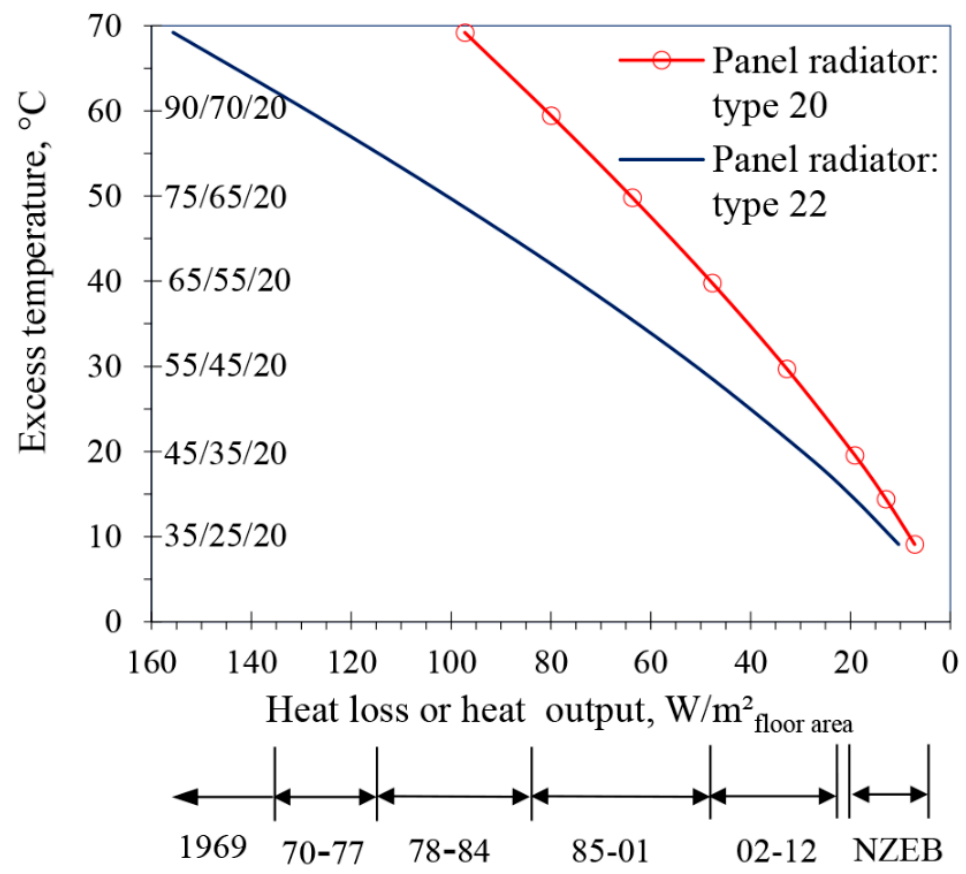

Figure 3. The evolution of energy efficiency in German buildings between 1969 and 2012 [42]. The values on the right hand side of ordinate (y-axis) show supply/return/room temperatures. Radiator dimensions: length $=1.2 \mathrm{~m}$, height $=0.5 \mathrm{~m}$. NZEB $=$ Near-Zero Energy Building. 


\subsection{Benefits of Low-Temperature Heating}

In the previous section, it was shown that the rate of thermal insulation of a building had a large impact on the operational mode of space heaters and their capability to be operated with a low-temperature water supply. In this section, another factor that has also an important impact on the system performance will be explored, namely, the thermal efficiency of the space heaters.

Figure 4a shows variation of heat loss with outdoor temperature for a typical Scandinavian single-family dwelling built up to 2000 . In the figure below, Figure $4 \mathrm{~b}$, the supply water temperatures required to compensate for the heat loss shown in Figure $4 \mathrm{a}$, for a conventional radiator, for baseboard radiators, and for floor heating are shown, respectively.

By following the red line in Figure $4 \mathrm{~b}$, it can be observed that the selected baseboard radiator system was able to cover a heat loss of about $29 \mathrm{~W} / \mathrm{m}^{2}$ per floor area using a $46^{\circ} \mathrm{C} / 36^{\circ} \mathrm{C}$ system. According to Figure $4 \mathrm{a}$, this heat loss would occur at an outdoor temperature of about $-1.7^{\circ} \mathrm{C}$ in the selected single-family dwelling. Figure $4 \mathrm{~b}$ further reveals that used floor heating could compensate for the same heat loss with an approximately $10{ }^{\circ} \mathrm{C}$ lower supply temperature. That is, by using a $36{ }^{\circ} \mathrm{C} / 31{ }^{\circ} \mathrm{C}$ system. With a conventional radiator, $51{ }^{\circ} \mathrm{C} / 41{ }^{\circ} \mathrm{C}$ system is required to cover the same loss. This implies that, to overcome the same heat loss $\left(29 \mathrm{~W} / \mathrm{m}^{2}\right.$ floor area $)$, the chosen conventional radiator must be operated with $5{ }^{\circ} \mathrm{C}$ and $15^{\circ} \mathrm{C}$ higher supply water temperatures, respectively, than the selected baseboard and floor heating system. Furthermore, the data in Figure $4 a, b$ indicates that all three analyzed space heaters would be able to cover a heat loss of about $20 \mathrm{~W} / \mathrm{m}^{2}$ floor area with water supplies lower than $45^{\circ} \mathrm{C}$. This means that most current heating systems could be operated with low-temperature supplies if the heat loss from a building would be sufficiently low.

The change of HSPF with water supply temperature used in Figure $4 b$ is illustrated in Figure $4 c$, and the change of $\mathrm{CO}_{2}$ emissions with $\mathrm{HSPF}$ used in Figure $4 \mathrm{c}$ was shown in Figure $4 \mathrm{~d}$. Figure $4 \mathrm{~d}$ shows that both HSPF and $\mathrm{CO}_{2}$ emissions are affected by the water supply temperature used in a heating system. According to Figure $4 \mathrm{c}$, the HSPF increases by approximately $1.3 \% /{ }^{\circ} \mathrm{C}$ for a decrease of supply temperature from $55^{\circ} \mathrm{C}$ to $30^{\circ} \mathrm{C}$. This increase rate of HSPF corresponds to the reduction rate of $\mathrm{CO}_{2}$ emissions in Figure $4 \mathrm{~d}$. Therefore, by replacing conventional radiators with floor heating in the considered dwelling, the HSPF would be increased by $17 \%$ and the $\mathrm{CO}_{2}$ emissions would be reduced by about $70 \mathrm{~kg}$ per heating season.

In order to better understand and to get a greater insight into how the parameters presented in Figures 2, 3 and $4 \mathrm{a}-\mathrm{d}$ are interconnected, Table 3 gives a brief summary of the mutual interconnections. It can be observed that increased outdoor temperature, improved thermal insulation of the building envelope would lower the heat loss of the building, this together with efficient space heaters would decrease the total electricity usage for heating and $\mathrm{CO}_{2}$ emissions from the building. It should be noted, however, that the rate of thermal insulation of a building and the efficiency of its heating system are not always necessarily interdependent. 


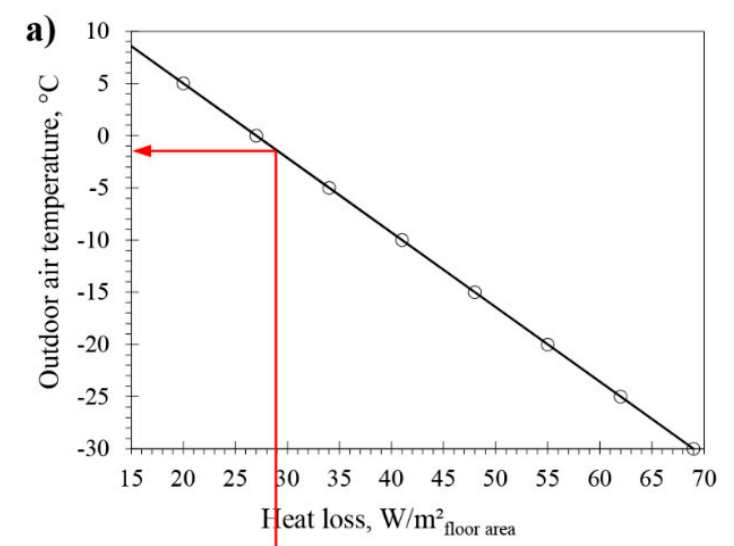

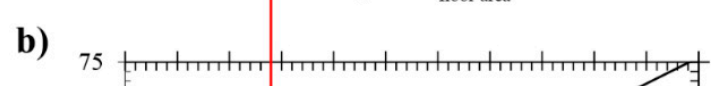
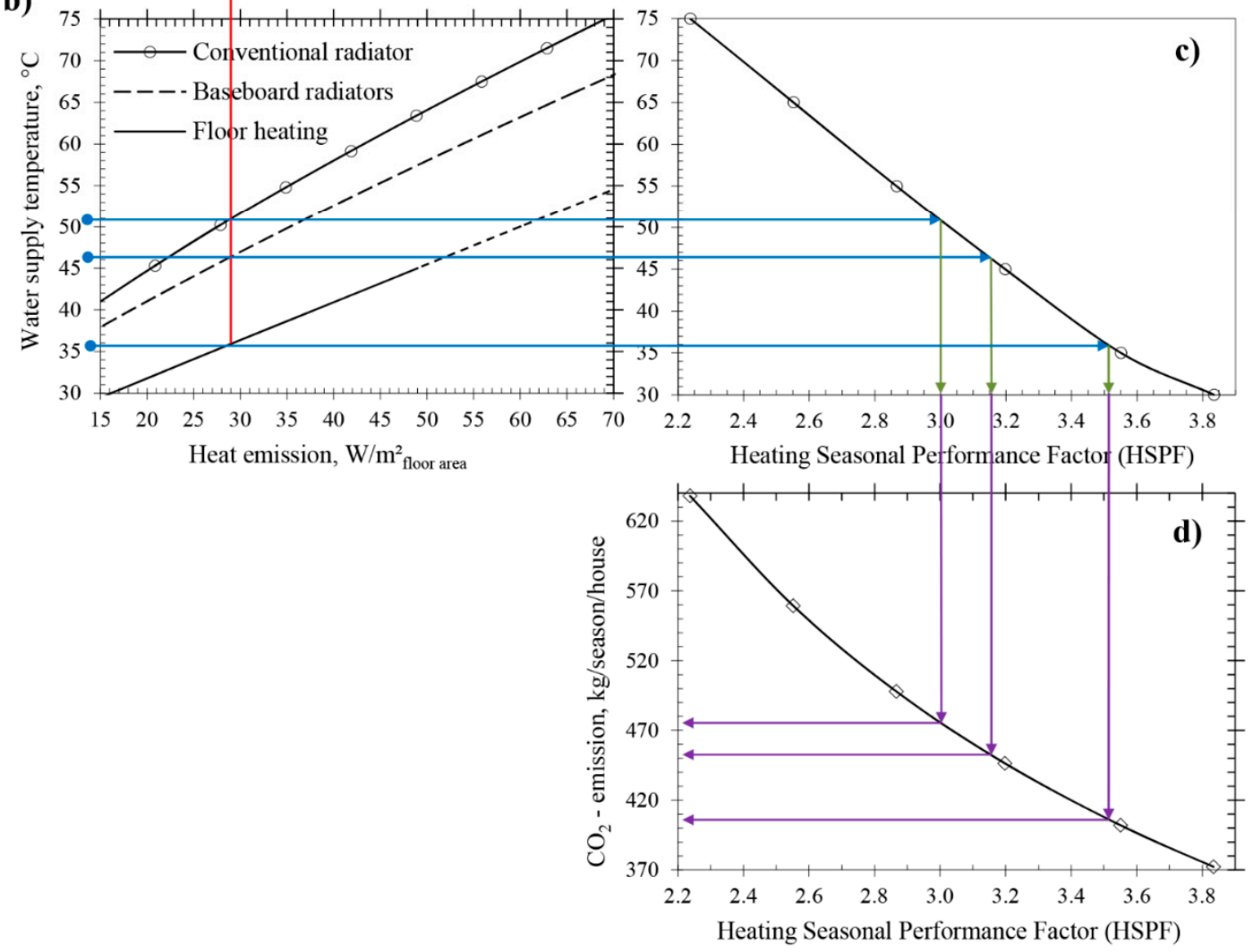

Figure 4. (a) Variation of heat loss versus outdoor temperature for a Scandinavian single-family dwelling built before 2000. Room floor area $=20 \mathrm{~m}^{2}$. (b) The required supply water temperatures for conventional and baseboard radiators and floor heating to cover heat loss from the considered dwelling. (c) The variation of HSPF with supply water temperature for a $6.4 \mathrm{~kW}$ GSHP installed in the considered dwelling. (d) The variation of $\mathrm{CO}_{2}$ emissions as a function of HSPF for the used dwelling.

Table 3. A summary of the interconnections between parameters presented in Figures 2, 3 and 4a-d.

\begin{tabular}{ccccc}
\hline \multicolumn{2}{c}{ Figure 4a } & Figure 4b & Figure 4c & Figure 4d \\
\hline $\begin{array}{c}\text { Outdoor temperature } \\
\text { Decreases }\end{array}$ & $\begin{array}{c}\text { Heating demand } \\
\text { Increases }\end{array}$ & $\begin{array}{c}\text { Supply temperature } \\
\text { Increases }\end{array}$ & $\begin{array}{c}\text { HSPF } \\
\text { Decreases }\end{array}$ \\
\hline $\begin{array}{c}\text { Thermal insulation } \\
\text { Increases }\end{array}$ & $\begin{array}{c}\text { Heating demand } \\
\text { Decreases }\end{array}$ & $\begin{array}{c}\text { Supply temperature } \\
\text { Decreases }\end{array}$ & $\begin{array}{c}\text { FSPF } \\
\text { Increases }\end{array}$ & $\begin{array}{c}\mathrm{CO}_{2} \\
\text { Decreases }\end{array}$ \\
\hline
\end{tabular}




\subsection{Hydraulic Pressure and Power Losses in Low-Temperature Systems}

In the previous section it was shown that low-temperature space heaters connected to a closed-loop heat pump could significantly reduce the energy use and $\mathrm{CO}_{2}$ emission of a single-family dwelling. However, the investigated space heaters in the previous sections were assessed according to current operational practice. The performance of radiator systems were evaluated at a temperature drop of $10{ }^{\circ} \mathrm{C}$, and floor heating system was assessed at a temperature drop of $5{ }^{\circ} \mathrm{C}$.

In this section the effects of smaller temperature drops (high water flow rates) will be thoroughly investigated. It is a well-known fact that water flow rates in low-temperature systems are usually much higher than in high-temperature system. If distribution pipes are not sized properly, this may significantly increase the electrical power required by the circulation pumps. In order to minimize the required pumping power, the inner diameter of each pipe section in a hydronic network must be selected with great care. In the following paragraphs, the influence of increased water flow rate and the inner pipe diameter on the pressure loss and pumping power need is evaluated. From here on in, the inner pipe diameter is referred to as pipe diameter only.

Figure 5 compares the increase of hydraulic pressure loss with increased water flow rate for pipe diameters currently used in floor and radiator systems in single-family dwellings. In order to maintain the current design guide value at around $100 \mathrm{~Pa} / \mathrm{m}$ for hydraulic pressure loss in distribution pipes, pipe diameters of 7.7, 10 and $13 \mathrm{~mm}$ are required for water flow rates of $0.01,0.017$ and $0.034 \mathrm{~kg} / \mathrm{s}$, respectively. In other words, an increase of pipe diameter from 7.7 to $13 \mathrm{~mm}$ (by 69\%) would allow an increase water flow rate from 0.01 to $0.034 \mathrm{~kg} / \mathrm{s}$ (by $240 \%$ ) without increasing the pipe pressure loss in a circuit.

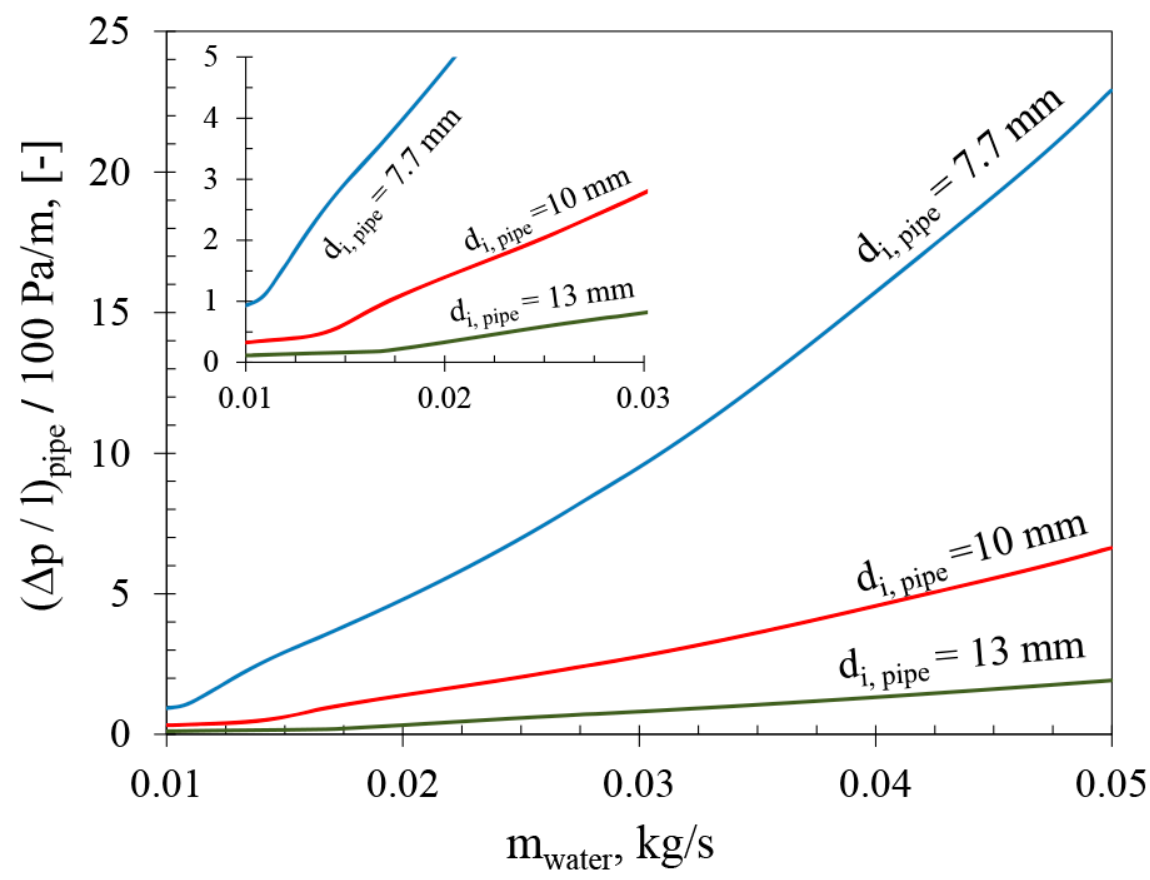

Figure 5. The increase of hydraulic pressure loss with increase of water mass flow rates for three pipe diameters usually used in floor and radiator heating systems.

Figure 6 shows the change in ratio between the pumping power need and the heat output with increased water flow rate for a floor heated room of $20 \mathrm{~m}^{2}$. In accordance with the manufacturers' suggestions, the pipe length, $1_{\text {pipe, }}$ of the underfloor heating circuit and the pump efficiency, $\eta_{\text {pump }}$, were set at $70 \mathrm{~m}$ and $25 \%$, respectively $[43,44]$. The water supply temperature was held at $35^{\circ} \mathrm{C}$, and water flow rate was increased from initial $0.009 \mathrm{~kg} / \mathrm{s}$ to $0.05 \mathrm{~kg} / \mathrm{s}$. 


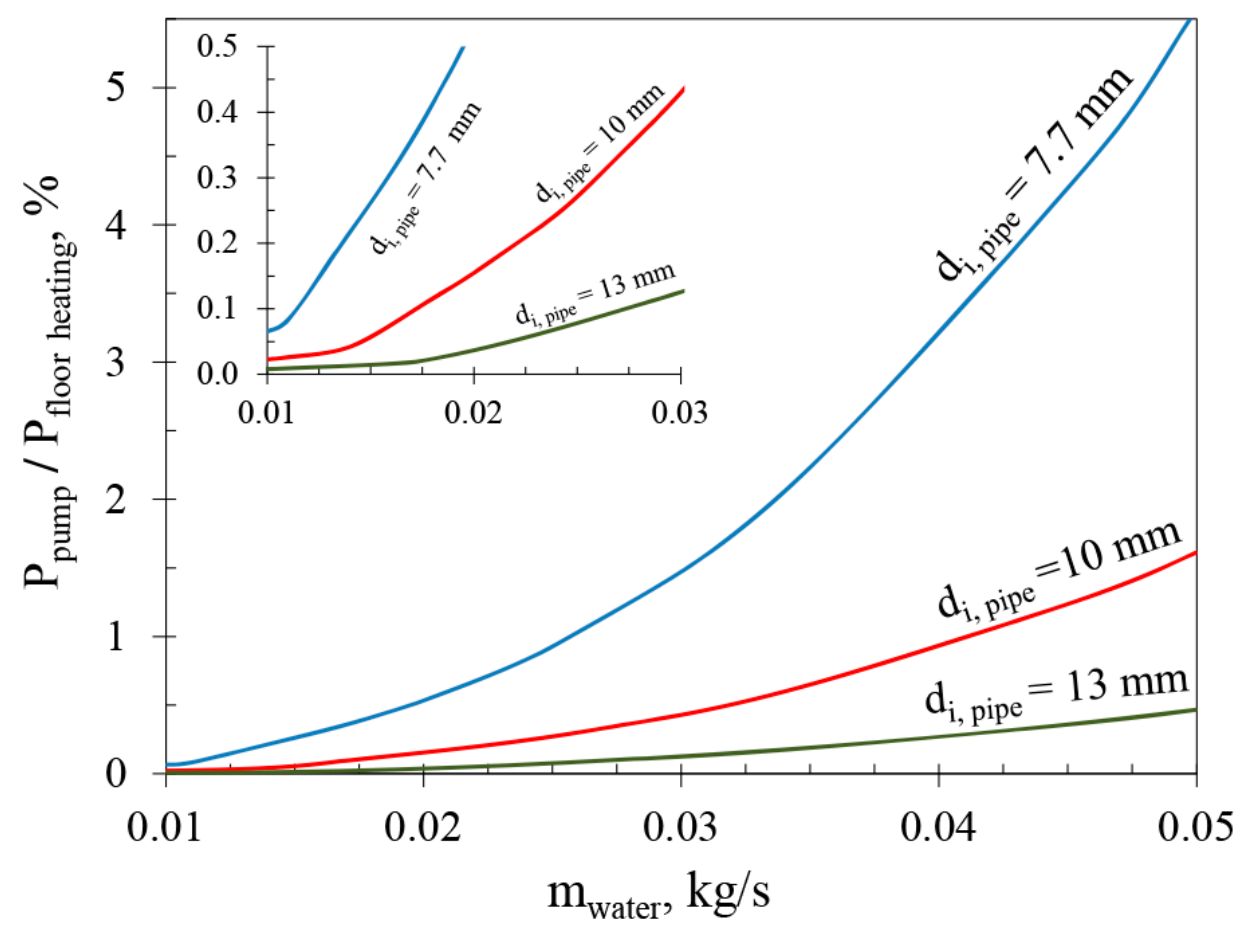

Figure 6. The variation of ratio between pumping power need and produced heat output with water flow rate in a floor heated room of $20 \mathrm{~m}^{2}$ floor area. $\theta_{\text {supp }}=35^{\circ} \mathrm{C}$.

By combining data from Figures 5 and 6, it can be observed that the pumping power need for a pipe diameter of $10 \mathrm{~mm}$ is $0.1 \%$ of produced heat output at hydraulic pressure loss of $100 \mathrm{~Pa} / \mathrm{m}$. By increasing the diameter to $13 \mathrm{~mm}$, the ratio would increase to $0.17 \%$ but the water flow rate would increase by 2 times. Even by allowing the pressure loss to increase to $344 \mathrm{~Pa} / \mathrm{m}$, the pumping power need would still be about $0.6 \%$ of the generated heat output for distribution pipes of $10 \mathrm{~mm}$. It also shows that the pressure loss would be about $195 \mathrm{~Pa} / \mathrm{m}$ when increasing the diameter to $13 \mathrm{~mm}$ and water flow rate to $0.05 \mathrm{~kg} / \mathrm{s}$, and that the ratio between the required pumping power and produced heat output would be about $0.5 \%$ in that case.

However, although it was fully possible to use a water flow of $0.05 \mathrm{~kg} / \mathrm{s}$ per circuit in floor heating systems, there is no practical justification to go above $0.035 \mathrm{~kg} / \mathrm{s}$. According to Table 4, an increase from $0.035 \mathrm{~kg} / \mathrm{s}$ to $0.05 \mathrm{~kg} / \mathrm{s}$ per circuit would increase pumping power need by $170 \%$ but this increase would only improve Coefficient of Performance (COP) of the considered GSHP by $2 \%$.

Figures 5 and 6 clearly show that pumping requirements in hydronic systems can easily be reduced by a proper pipe design. Table 4 also shows that it would be beneficial to use water flow of a high rate in a floor heating system supported by a heat pump. According to the table, an increase of water flow rate from $0.01 \mathrm{~kg} / \mathrm{s}$ to $0.035 \mathrm{~kg} / \mathrm{s}$ per circuit would improve the COP of the considered GSHP by $17 \%$. Therefore, the traditional design guide values for hydraulic pressure loss of 100 Pa per meter pipeline and water flow rate of $0.01 \mathrm{~kg} / \mathrm{s}$ per circuit are not always suitable for low-temperature heating systems in single-family houses.

It should be noted that the ratio between the pumping power need and the heat output for radiator systems would be even lower than for floor heating, since the total length of distribution pipes in radiator heating is normally much shorter compared to floor heating systems. It is therefore safe to conclude that the design guideline values of $100 \mathrm{~Pa} / \mathrm{m}$ for water-side pressure loss in distribution pipes and of $0.01 \mathrm{~kg} / \mathrm{s}$ per circuit for water flow rate are not fully appropriate for design of low-temperature heating systems in single-family dwellings. 
Table 4. The heat emission, pump power need and heat pump efficiency (COP) of a floor heated room of $20 \mathrm{~m}^{2}$ floor area. Pipe length of heating circuit was set to $70 \mathrm{~m}$ and pipe diameter to $13 \mathrm{~mm}$. Energy need for DHW is not considered.

\begin{tabular}{|c|c|c|c|c|c|c|c|c|}
\hline \multirow{2}{*}{$\begin{array}{c}\begin{array}{c}\text { Heat } \\
\text { Emission }\end{array} \\
\mathrm{P}_{\text {heat }} / \mathrm{A}_{\text {floor }}\end{array}$} & \multirow{2}{*}{$\begin{array}{l}\text { Pipe Length } \\
1_{\text {pipe }} / A_{\text {floor }}\end{array}$} & \multirow{2}{*}{$\begin{array}{c}\text { Supply } \\
\theta_{\text {supp }}\end{array}$} & \multirow{2}{*}{$\frac{\text { Return }}{\theta_{\mathrm{rtn}}}$} & \multicolumn{2}{|c|}{ Water Flow } & \multicolumn{2}{|c|}{ Pump Power Need } & \multirow{2}{*}{$\frac{\mathrm{COP}}{\mathrm{P}_{\text {cond }} / \mathrm{P}_{\text {comp }}}$} \\
\hline & & & & $\dot{\mathrm{m}}_{\text {water }} /$ circuit & $\begin{array}{c}\left(\dot{\mathrm{m}}_{\text {water }} / \mathrm{A}_{\text {floor }}\right) \\
\times 3600\end{array}$ & $\mathrm{P}_{\text {pump }} / \dot{\mathrm{m}}_{\text {water }}$ & $\begin{array}{c}\left(\mathrm{P}_{\text {pump }} / \mathrm{P}_{\text {heat }}\right) \times \\
100\end{array}$ & \\
\hline 29 & 3.5 & 41.0 & 27.5 & 0.01 & 1.8 & 3.2 & $5.5 \times 10^{-3}$ & 4.1 \\
\hline 29 & 3.5 & 35.1 & 31.1 & 0.035 & 6.3 & 28 & 0.17 & 4.8 \\
\hline 29 & 3.5 & 34.8 & 32.0 & 0.05 & 9.0 & 54 & 0.47 & 4.9 \\
\hline
\end{tabular}

\subsection{The Impact of Increased Water Flow Rate on Heat Output and Exergy Use}

It is important to further evaluate the validity of using high water flow rates in heating systems. Therefore, the focus in this section is to evaluate the impact of increased water flow rate on heat output and exergy use of the considered heating systems, in other words, to rate the efficiency of natural resources utilization when using high water flow rates in heating systems.

Figure 7 illustrates the variation of the relative heat output with change of relative water flow for the analyzed space heaters. It shows that floor heating benefits most from increased water flow rate, followed by baseboard radiators, while conventional radiator benefitted the least from this increase. By increasing the water flow from 0.01 to $0.035 \mathrm{~kg} / \mathrm{s}$ the heat output from the considered floor, baseboard and conventional radiator heating systems increased by 38,28 and $25 \%$, respectively. Figure 7 also reveals that a $50 \%$ decrease of the initial water flow rate $(=0.01 \mathrm{~kg} / \mathrm{s})$ would reduce the heat output from the considered space heaters by 22 to $30 \%$. This clearly shows that the heat output from a high-flow system is largely affected by the operational water flow. Therefore, it is very important to fine-tune high-flow systems carefully in order to maximize their thermal performance.

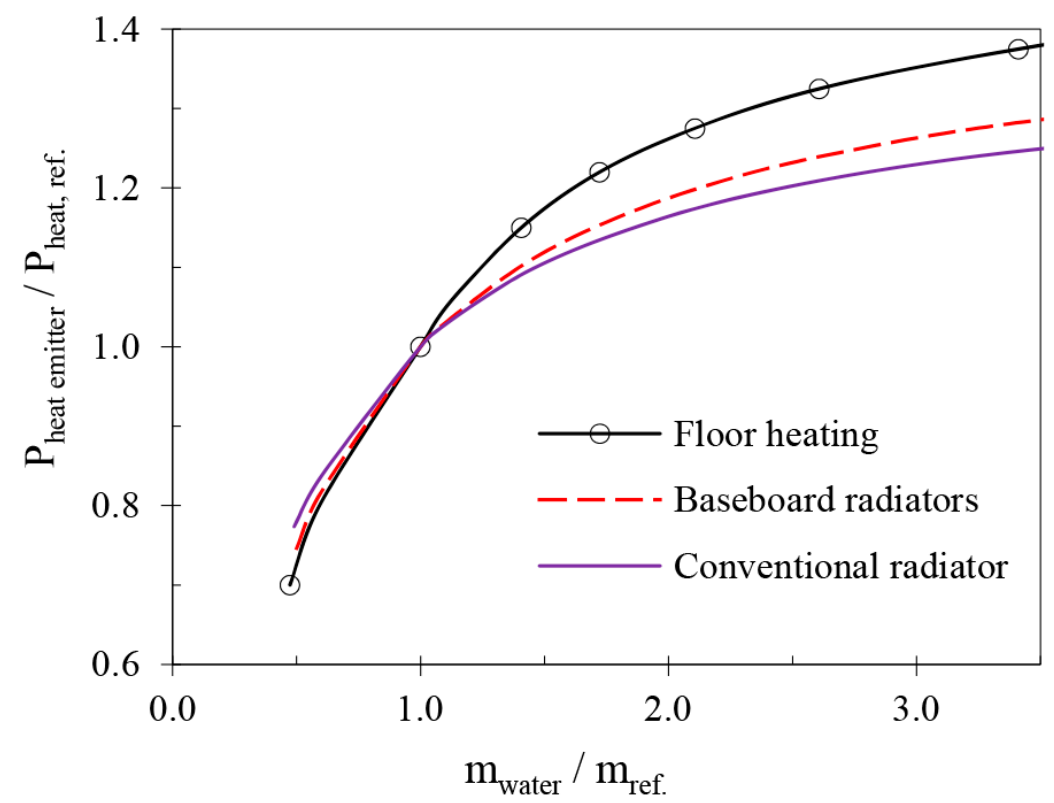

Figure 7. The variation of relative heat output with change in relative water flow rate for floor, baseboard and conventional radiator heating systems. The water flows are normalized by $\mathrm{m}_{\text {water, ref. }}=0.01 \mathrm{~kg} / \mathrm{s}$, and the heat outputs by corresponding output, $P_{\text {heat, ref., }}$ at $0.01 \mathrm{~kg} / \mathrm{s}$.

Figure 8 shows the variation of exergy use per unit mass of water with temperature dropped across the considered conventional radiator. Figure 8 reveals two things. First, the largest contributor of exergy use in a radiator system is the thermostatic valves. Second, a large temperature drop over the radiator requires a high exergy use. It shows that a radiator system with a temperature drop of 
$20{ }^{\circ} \mathrm{C}$ (low-flow system, $0.0074 \mathrm{~kg} / \mathrm{s}$ per radiator) would use about 4.1 times more exergy per unit mass of water than it would use when operated with a temperature drop of $5{ }^{\circ} \mathrm{C}$ (high-flow system, $0.0283 \mathrm{~kg} / \mathrm{s}$ per radiator). This suggests that high-flow $/$ low-temperature systems are more exergy efficient than low-flow/high-temperature systems.

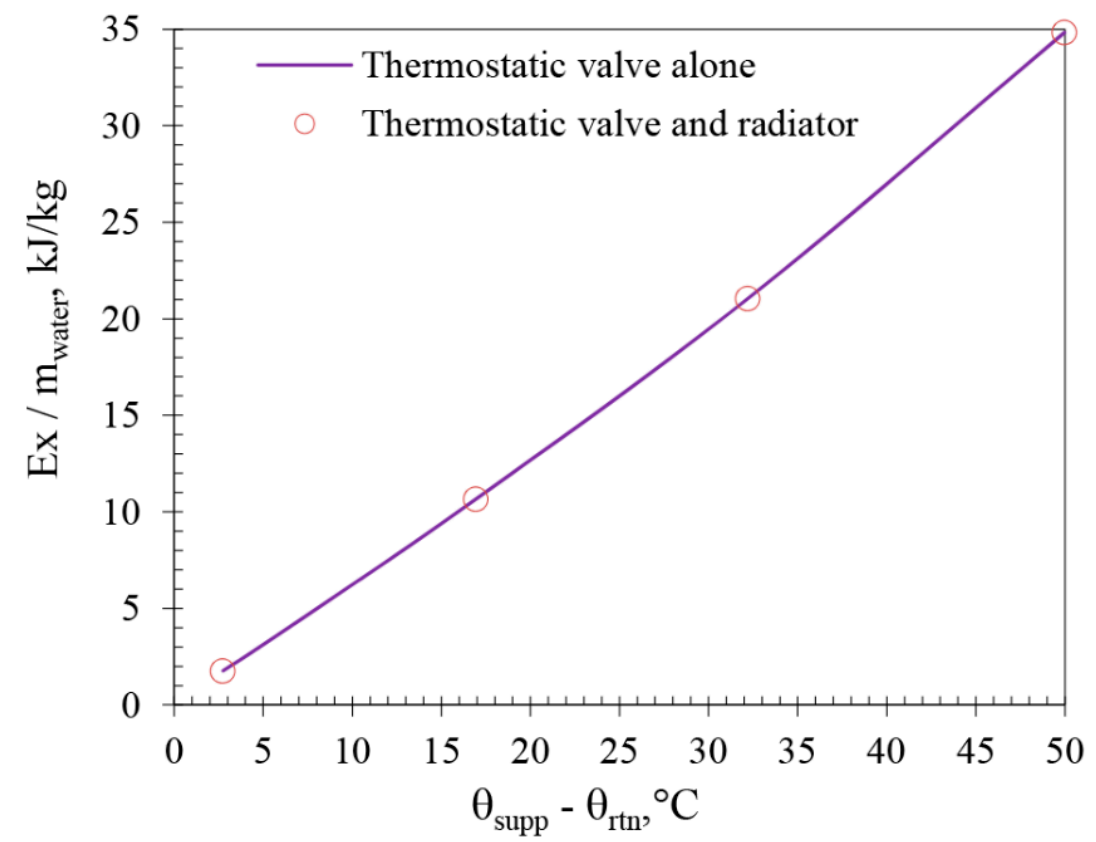

Figure 8. The variation of exergy use per unit mass of water at different temperature drops across a conventional radiator. The calculations are based on a $\mathrm{K}_{\mathrm{v}}$-value of 0.45 .

\subsection{The Impact of Increased Water Flow Rate on Noise Production}

In the previous section, it was shown that high water flow rates in well-designed hydronic systems may significantly increase their heat outputs and decrease their exergy use. However, the high water flow rates could also generate high noise levels, which may annoy the occupants. In hydronic systems, the thermostatic valves are usually associated with noise problems. The noise generation inside a valve is closely related to the pressure loss over it, which mainly depends on the operating flow rate and the flow capacity of the valve $\left(\mathrm{K}_{\mathrm{v}}\right.$-value). Presently, the $\mathrm{K}_{\mathrm{v}}$-values for self-operated thermostatic valves range from about 0.01 to $2.0 \mathrm{~m}^{3} / \mathrm{h}$ in hydronic systems [45]. $\mathrm{K}_{\mathrm{v}}$-values between 0.03 and $0.04 \mathrm{~m}^{3} / \mathrm{h}$ are currently used in low-flow/high-temperature systems [13], while values of about $0.7 \mathrm{~m}^{3} / \mathrm{h}$ are presently used for high-flow/low-to-medium temperature systems [46].

According to current best practice, to avoid noise generation, the total pressure loss over the thermostatic valve and the heating appliance should be below $10 \mathrm{kPa}$ [46]. According to Figure 9, in order to keep the total pressure over the valve and considered radiator below $10 \mathrm{kPa}$ at a water flow of $0.035 \mathrm{~kg} / \mathrm{s}, \mathrm{K}_{\mathrm{v}}$-value of the thermostatic valve should be higher than $0.4 \mathrm{~m}^{3} / \mathrm{h}$. By increasing the $\mathrm{K}_{\mathrm{v}}$-value to $0.45 \mathrm{~m}^{3} / \mathrm{h}$, the total pressure loss would decrease to $8.3 \mathrm{kPa}$ at $0.035 \mathrm{~kg} / \mathrm{s}$. By further increasing the $\mathrm{K}_{\mathrm{v}}$-value to $0.5 \mathrm{~m}^{3} / \mathrm{h}$, the total pressure loss would drop to about $6.8 \mathrm{kPa}$. This increase of $\mathrm{K}_{\mathrm{v}}$-value from 0.4 to $0.5 \mathrm{~m}^{3} / \mathrm{h}$ (by $25 \%$ ) would reduce the risk of unwanted noise by a factor of 1.5 . This is clear evidence that it was fully feasible to operate the considered heating systems with high water flow rates without creating unwanted noise problems in single-family dwellings. 


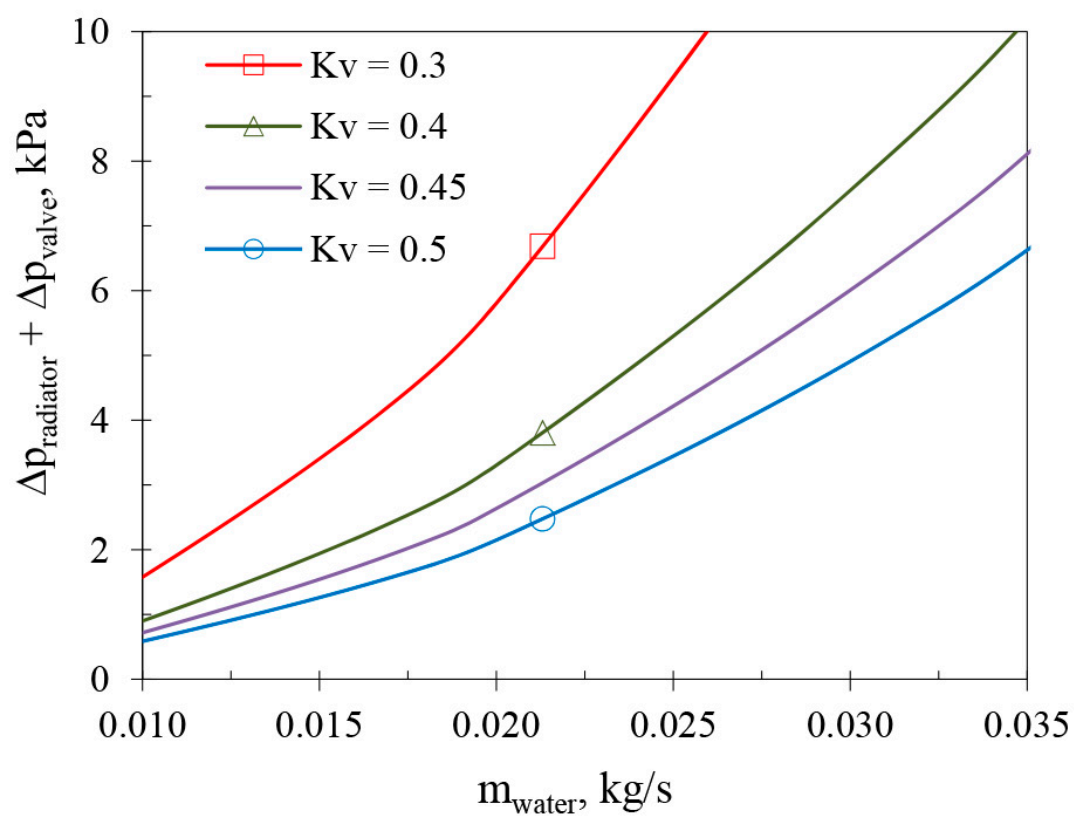

Figure 9. The pressure loss over a thermostatic valve and a conventional radiator at different water flow rates for four $\mathrm{K}_{\mathrm{v}}$-values.

\subsection{Uncertainty of Presented Results}

Previous studies have shown that the simulated heat loss signature was $5 \%$ below the measured one presented in Figure 4a [47], and that the heat outputs given in Figure 4b agreed with the laboratory measurements within $\pm 2 \%$ [28]. A previous report also concluded that even the most advanced and detailed calculation models for the prediction of heat pump performance had an uncertainty of up to $10 \%$ [48]. This implies that the uncertainty of the HSPF-values presented in Figure $4 \mathrm{c}$ should also be within $\pm 10 \%$, at best. According to the Swedish Energy Agency [49], in 2008 the combined $\mathrm{CO}_{2}$ emissions for electricity generation in Scandinavian countries amounted to 75-100 kg per MWh. This means that there is an uncertainty in the $\mathrm{CO}_{2}$ emissions shown in Figure $4 \mathrm{~d}$, which is within $\pm 15 \%$ of those of the presented graph. In addition, for hydraulically smooth pipes, the uncertainty in the prediction of the pipe friction factor is estimated to $\pm 5 \%$ [50]. This means that predictions of pressure loss and pumping power need in Figures 5 and 6, respectively, should also fall approximately within that range. Finally, according to the prevailing norm, the uncertainty of the preset valve throttling $\left(\mathrm{K}_{\mathrm{v}}\right.$-value) must not exceed 10\% [32]. Consequently, the uncertainty of the pressure loss shown in Figure 9 should not be greater than $\pm 10 \%$. Taking all these factors into account, it can be concluded that the results presented in this study fall within commonly accepted engineering levels of accuracy.

\section{Discussion}

The literature review conducted in this study has revealed that the classification of hydronic systems according to their operational temperatures is arbitrary, and has been constantly changing over time. It seems, however, that since around the year 2000, there has been a general agreement that heating systems that are able to cover heat loss with water supplies of $45^{\circ} \mathrm{C}$ and below should be regarded as low-temperature heating systems. It is, however, still unclear which outdoor temperature should be used when considering the heat loss; that is, whether the heat load should be considered at the design, at the mean winter, or at the mean annual outdoor temperature.

A common perception among today's heating, ventilation and air conditioning (HVAC) engineers is that thermal benefits of using high water flow rates (higher than $0.01 \mathrm{~kg} / \mathrm{s}$ per appliance/circuit) in heating systems may be outweighed by the increased power needed for the circulation pumps and the cost increase for the distribution pipes. In this study, it was proved that this common conviction 
does not hold for well-designed hydronic systems adapted for operation with high water flow rates. Figure 10 shows variation of optimum pipe diameter with water flow rates between $0.01 \mathrm{~kg} / \mathrm{s}$ and $0.035 \mathrm{~kg} / \mathrm{s}$. As seen, economic pipe diameter for $0.035 \mathrm{~kg} / \mathrm{s}$ is approximately $8.5 \mathrm{~mm}$. This value is within $\pm 1.5 \mathrm{~mm}$ interval of pipe diameters used in this study $(7.7 \mathrm{~mm}$ and $10 \mathrm{~mm})$. This proves that pipe diameters commonly used for water distribution in current hydronic systems can also be used for high-flow systems. Figure 11 demonstrates the change of COP of the analyzed GSHP with increased water flow rate and supply water temperature in a hydronic system. Not surprisingly, COP is mostly affected by the level of supply water temperature of the heating system. A reduction of the supply temperature from $50{ }^{\circ} \mathrm{C}$ to $30^{\circ} \mathrm{C}$ would improve the $\mathrm{COP}$ by a factor of 1.4. Moreover, COP would increase by $14 \%$ by reducing the temperature drop from $30^{\circ} \mathrm{C}$ to $5{ }^{\circ} \mathrm{C}$ in a heating system with a supply temperature of $50{ }^{\circ} \mathrm{C}$. The corresponding increase would be $13 \%$ in a heating system with a supply temperature of $40{ }^{\circ} \mathrm{C}$ if the temperature drop would be decreased from $20{ }^{\circ} \mathrm{C}$ to $3{ }^{\circ} \mathrm{C}$. This shows that heating systems supported by domestic heat pumps should be operated with low-temperature water supplies and high water flow rates.

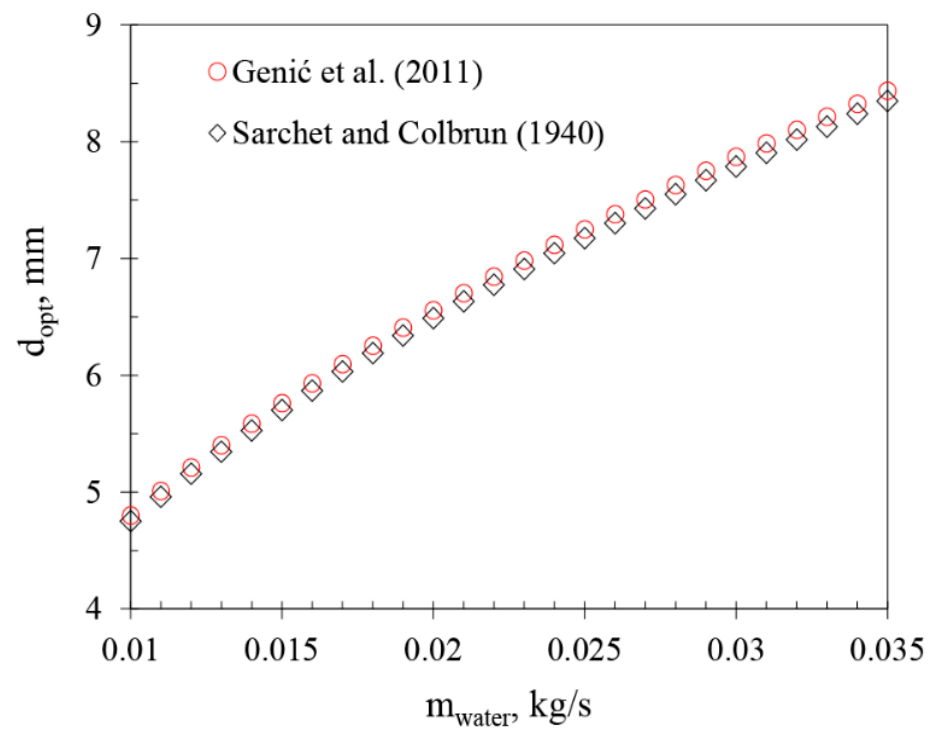

Figure 10. Change of economic optimum pipe diameter with water flow rate according to [51,52].

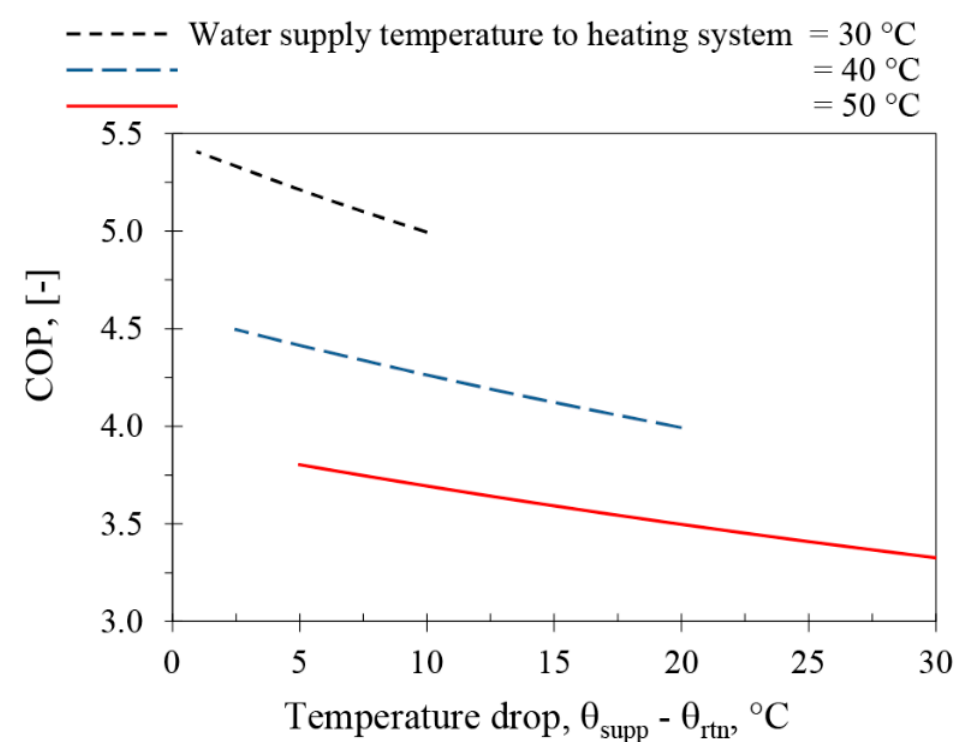

Figure 11. Variation of COP with temperature drop across a heating system in a single-family dwelling. Maximum water flow rate $0.035 \mathrm{~kg} / \mathrm{s}$ per heating appliance. 
The evidence presented in this study indicates that well-designed low-temperature heating systems may significantly decrease the energy use in a single-family dwelling. It showed that the use of floor heating instead of conventional radiators in a typical Scandinavian single-family dwelling would increase the efficiency of a closed-loop heat pump by about $17 \%$, and that the use of baseboard radiators instead of conventional radiators would increase the heat pump efficiency by about $7 \%$. It was shown that the capacity of a heating system to be operated with water supply lower than $45^{\circ} \mathrm{C}$ is determined to a large extent by the heating demand of a building. The thermal insulation of a building and the efficiency of heat recovery from the used ventilation air are thus key factors for a hydronic heating system to be operated with low-temperature supply.

It was revealed that the commonly used design guideline values of $100 \mathrm{~Pa} / \mathrm{m}$ for water-side pressure loss in distribution pipes and $0.01 \mathrm{~kg} / \mathrm{s}$ for water flow rate per heating circuit are not suitable for low-temperature heating systems in single-family dwellings. It was shown that the pumping power need would be about $0.6 \%$ of the emitted heat output for a floor heating system with distribution pipes of $10 \mathrm{~mm}$, even if the pressure loss was about 3.5 times higher than the currently recommended guideline value $(100 \mathrm{~Pa} / \mathrm{m})$. For a pipe diameter of $13 \mathrm{~mm}$ the pumping need to heat output ratio would be approximately $0.2 \%$, even when the water flow is 3.5 times higher than commonly used in nowadays hydronic system $(0.01 \mathrm{~kg} / \mathrm{s}$ per circuit or space heater). On the other hand, this increase of water flow would increase the heat output from the considered floor heating system by $38 \%$.

It was also found that a water flow rate of $0.035 \mathrm{~kg} / \mathrm{s}$ per appliance would not generate unwanted noise if the $\mathrm{K}_{\mathrm{v}}$-value of the thermostatic valve was set at a value higher than $0.45 \mathrm{~m}^{3} / \mathrm{h}$. This implies two things: firstly, the water flow rates in current heating systems could be significantly increased if the distribution pipes were properly sized and thermostatic valves correctly chosen; secondly, if this measure is taken, the heat output from current heating systems could be significantly increased. However, it is important to remember that high water flow rates requires a distribution network that is well-balanced and carefully thought out. Otherwise, the result may be the opposite of that required.

The results also showed that a radiator system that operates with small temperature drops requires significantly less exergy use than when it is operated with large temperature drops (low water flow rates). This implies that high-flow/low-temperature heating systems are more environmentally friendly than low-flow/high-temperature systems, since low-temperature systems use less natural resources for operation. A practical implication of this finding is that low-temperature heating systems connected to heat pumps should be operated with small temperature drops in single-family dwellings.

The use of a high flow water rate in a heating system had also a positive effect on heat pump performance. With increased water flow rate, the temperature drop over space heaters come closer to the temperature drops of evaporators and condensers in heat pumps. This decreased the required temperature lift in the heat pump and increased its efficiency (COP-value). This finding is in line with previous results reported in [53]. However, although small temperature drops in heating systems would result in higher COP-values for heat pumps this is still not always engineering practice. Nevertheless, in this study it was shown that the use of high water flow rates in well-designed hydronic systems would increase efficiency of the heat pump and generate energy savings.

The results presented in this study indicate that heat pump efficiency (COP) would increase by about $1.3 \% /{ }^{\circ} \mathrm{C}$ for a supply temperature reduction from $55{ }^{\circ} \mathrm{C}$ to $30^{\circ} \mathrm{C}$. In the considered case domestic hot-water and circulators constituted about $20 \%$ of the total heating energy need. By reducing these two energy needs by $50 \%$, the improvement of heat pump efficiency would increase to $2.1 \% /{ }^{\circ} \mathrm{C}$ of reduced supply temperature. In that case, the efficiency of the considered heat pump would be improved by roughly $10 \%$ when increasing the water flow rate from 0.01 to $0.035 \mathrm{~kg} / \mathrm{s}$ per heating appliance in a radiator system. This simple example demonstrates the importance of the reduction of these two energy needs. Therefore, in order to fully utilize the entire potential of low-temperature heating systems in single-family houses, the energy demands required by the domestic hot-water and circulation pumps must be reduced. An important subject that remains to be explored is how the 
energy required for the preparation of domestic hot-water could be reduced in single-family dwellings served by heat pumps in an efficient and practical way.

The results of the present study suggested that the $\mathrm{CO}_{2}$ emissions from a single-family dwelling could be significantly reduced by using efficient low-temperature space heaters together with an efficient heat pump. However, it should be noted that this depends to a large extent on the cleanness of the primary energy used. For example, in 2008 in the European Union countries, about $360 \mathrm{~kg}$ of $\mathrm{CO}_{2}$ emission was required to produce $1 \mathrm{MWh}$ of electricity [54]. The corresponding emission rates for the same period in Sweden and the Scandinavian countries were on average 15-25 kg and 75-100 kg, respectively [49]. This implies that in the year 2008, electricity production in Sweden and in Scandinavian countries as a whole was about 18 and 4 times cleaner, respectively, compared with the European Union. This clearly illustrates that the use of renewables for energy supply in the building sector is of vital importance for sustainability.

There are also some practical implications that should be taken into account when considering the overall performance of the heating systems investigated in this study. For example, the heat emission from the considered systems was to a large extent controlled by the dimensions and types of the space heaters. Bigger conventional radiators with more panels and secondary surfaces (convector plates), or longer and higher baseboard radiators, would emit more heat. This would result in an operation close to floor heating. On the other hand, a denser arrangement of distribution pipes in floor heating would also greatly increase the heat output from this system. This would on the other hand also require a higher pumping work for water circulation. It is therefore important to take these parameters into account when weighting the overall performance of the considered heating systems.

\section{Conclusions}

This paper demonstrated the wider context of importance of increasing the efficiency of current space heaters connected to closed-loop heat pumps in single-family dwellings. The study was divided into two parts. The main goal of the first part of the study was to map the parameters that mainly control the thermal performance of space heaters commonly used in single-family dwellings. The second part explored in detail the potential of using water supplies of high flow rates in the considered heating systems. Both parts aimed to provide practical insights and guidelines for the design and more efficient operation of heating systems in single-family dwellings. Based on the results, the following can be concluded:

- The capacity of a heating system to be operated with a water supply below $45^{\circ} \mathrm{C}$ is determined to a large extent by the heating demand of a building. The size, type and efficiency of space heaters are also important factors but the heating demand is the deceive factor for efficient operation of heating systems with low-temperature water supplies.

$\bigcirc$ Well-designed and well-operated low-temperature space heaters in combination with efficient heat pumps may significantly decrease the final energy use of single-family dwellings in cold countries.

$\bigcirc$ The current guideline design values of $100 \mathrm{~Pa} / \mathrm{m}$ for water-side pressure loss in distribution pipes and $\leq 0.01 \mathrm{~kg} / \mathrm{s}$ for water flow per space heater or heating circuit are set too low and are not appropriate for low-temperature heating systems in single-family dwellings.

○ The hydraulic pressure loss of 350 Pa per meter pipeline and water flow of $0.035 \mathrm{~kg} / \mathrm{s}$ per space heater or heating circuit should be used instead of traditional values $(100 \mathrm{~Pa} / \mathrm{m}$ and $\leq 0.01 \mathrm{~kg} / \mathrm{s})$ for low-temperature heating systems in single-family dwellings. The pumping power need after this increase would be about $0.2-0.6 \%$ of generated heat output for distribution pipes of 10-13 mm inner-diameter.

○ By increasing the water flow rate from 0.01 to $0.035 \mathrm{~kg} / \mathrm{s}$ per space heater, the heat output from the considered conventional radiator system increased by $25 \%$. This increase improved the 
efficiency of the considered heat pump (COP) by $6 \%$. An improvement of up to $10 \%$ could be achieved by reducing the energy needs for the domestic hot-water and circulation pumps by half.

○ There is no practical justification to use water flow rates higher than $0.035 \mathrm{~kg} / \mathrm{s}$ per space heater or heating circuit in heating systems supported by heat pumps in single-family dwellings.

0 In order to avoid unwanted noise generation, the flow coefficient $\left(\mathrm{K}_{\mathrm{v}}\right.$-value) of thermostatic valves should not be lower than $0.45 \mathrm{~m}^{3} / \mathrm{h}$ if a water flow of $0.035 \mathrm{~kg} / \mathrm{s}$ per heating appliance is to be used.

0 The hydronic heating systems that operate with small temperature drops $\left(\leq 5{ }^{\circ} \mathrm{C}\right)$ use significantly less exergy than systems with large temperature drops. It is thus important and environmentally beneficial to create the right preconditions for heating systems to be operated with low-temperature water supplies and high water flow rates.

0 Based on the conclusions listed above the following steps should be implanted to maximize the potential of low-temperature heating systems. First, the building heat loss should be minimized. Second, the thermal efficiency of space/room heaters should be maximized. Third, if possible, the temperature drop across the heating system should be held constant at about $5{ }^{\circ} \mathrm{C}$ or lower. Fourth, the heat pump connected to the low-temperature heating system should be operated with the dynamic heating curve.

Author Contributions: conceptualization, A.P., Q.W. and S.S.; methodology, A.P.; software, A.P.; validation, A.P., Q.W. and S.S.; formal analysis, A.P.; investigation, A.P., QW; data curation, A.P.; writing-original draft preparation, A.P.; writing-review and editing, A.P., Q.W. and S.S.; visualization, A.P., Q.W. and S.S.; project administration, A.P.; funding acquisition, A.P.

Funding: Financial support from the Swedish Construction Development Fund (SBUF-Svenska Byggbranschens Utvecklingsfond) is gratefully acknowledged. Project number: 13122.

Acknowledgments: The authors wish to thank Professor Sture Holmberg and Dr. Arefeh Hesaraki from Fluid and Climate Technology at KTH Royal Institute of Technology for their critical review and valuable suggestions.

Conflicts of Interest: The authors declare no conflicts of interest.

\section{Nomenclature}

\begin{tabular}{|c|c|c|}
\hline \multicolumn{3}{|c|}{ Abbreviations/Definitions } \\
\hline $\mathrm{CO}_{2}$ & Carbon dioxide & $\mathrm{kg}$ \\
\hline $\mathrm{COP}$ & Coefficient of Performance (Heat output/electricity input of heat pump) & - \\
\hline DHW & Domestic hot-water & \\
\hline EN & European Norm/Standard & \\
\hline GSHP & Ground Source Heat Pump & \\
\hline HVAC & Heating, Ventilation and Air Conditioning & \\
\hline HSPF & $\begin{array}{l}\text { Heating Seasonal Performance Factor (heat output/electricity input of entire } \\
\text { heating system including heat pump and circulators) }\end{array}$ & - \\
\hline IPCC & Intergovernmental Panel on Climate Change & \\
\hline $\operatorname{Re}$ & Reynolds number $=\frac{\mathrm{u}_{\text {pipe }} \mathrm{d}_{\text {pipe }}}{v_{\text {water }}}=\frac{4 \dot{m}_{\text {pipe }}}{\rho_{\text {water }} \pi \mathrm{d}_{\text {pipe }} v_{\text {water }}}$ & - \\
\hline Type 20 & Hydronic radiator with two panels & \\
\hline Type 21 & Hydronic radiator with two panels and a single convector plate & \\
\hline Type 22 & Hydronic radiator with two panels and two convector plates & \\
\hline \multicolumn{3}{|c|}{ Latin letters } \\
\hline$c_{p}$ & Specific heat capacity of water (4176 in this study) & $\mathrm{J} /\left(\mathrm{kg}^{\circ} \mathrm{C}\right)$ \\
\hline d & (Based on) inner pipe diameter & $\mathrm{m}$ \\
\hline Ex, $\dot{\mathrm{Ex}}$ & Exergy & W \\
\hline $\mathrm{F}$ & Factor & - \\
\hline $\mathrm{f}$ & Pipe (flow) friction factor & - \\
\hline
\end{tabular}


K Flow coefficient of valve (valve capacity)

$\mathrm{m}^{3} / \mathrm{h}$

Length of distribution pipes in a heating circuit

$\mathrm{m}$

Water mass flow rate

$\mathrm{kg} / \mathrm{h}$

$\dot{\mathrm{M}}$

Water mass flow rate

$\mathrm{kg} / \mathrm{s}$

$=\frac{P_{\text {heat emitter }}}{c_{\mathrm{p}, \text { water }}\left(\theta_{\text {supp }}-\theta_{\mathrm{rtn}}\right)}$

$\mathrm{kg} / \mathrm{s}$

$\mathrm{P} \quad$ Heat output or hydraulic pump power need

W

$\mathrm{p} \quad$ Pressure

$\mathrm{T} \quad$ Absolute (thermodynamic) temperature

Pa and bar

$\mathrm{K}$

Water velocity in pipes

$\mathrm{m} / \mathrm{s}$

$\dot{V} \quad$ Volume flow rate

$\mathrm{m}^{3} / \mathrm{h}$

Greek letters

$\Delta \quad$ Difference

$\varepsilon \quad$ Absolute inner pipe roughness $\left(1.5 \times 10^{-6}\right.$ in this study)

$\mathrm{m}$

Radiator entrance loss coefficient ( 3 in this study)

$-$

Hydraulic efficiency of water pump

Temperature

Kinematic viscosity

$-$

${ }^{\circ} \mathrm{C}$

$\mathrm{m}^{2} / \mathrm{s}$

Density

$\mathrm{kg} / \mathrm{m}^{3}$

Subscripts

comp Compressor

cond Condenser

circuit Heating circuit

el Electricity

eq. $\quad \mathrm{CO}_{2}$ equivalent and equivalent pipe length for components

heat Heat output of heat emitter

i First term in a sequence (first pipe line/circuit)

inlet Pipe inlet to radiator

lmtd Logarithmic mean temperature difference

n Number of pipe lines (circuits) and temperature exponent

opt Optimum

pipe Pipe

pump Pump

q Quality

radiator water-based (hydronic) radiator

ref. Reference value $\left(1000 \mathrm{~kg} / \mathrm{m}^{3}\right.$ in this study)

room Room air

rtn Return water from room (space) heater

supp Supply water to room (space) heater

v Valve

\section{References}

1. European Commission. Climate Strategies \& Targets. Climate Action-European Commission, 2016. Available online: https: / / ec.europa.eu/clima/policies/strategies_en (accessed on 28 September 2018).

2. Bonn, M.; Heitmann, N.; Götz, R.; Voßwinkel, J.S. EU Climate and Energy Policy 2030 Comments on an Evolving Framework; Centrum für Europäische Politik, cepInput: Freiburg, Germany, 2015; Available online: http://www.cep.eu/Studien/cepInput_Klima_und_Energie/cepInput_Climate_and_ Energy_Policy_2020-2030.pdf (accessed on 25 November 2015).

3. Bertoldi, P.; Hirl, B.; Labanca, N. Energy Efficiency Status Report 2012. Electricity Consumption and Efficiency Trends in the EU-27; Report EUR 25405 EN, JRC 69638; European Commission: Luxembourg, 2012.

4. Bauermann, K.; Weber, C. Chapter 14-Heating Systems When Little Heating Is Needed. In Energy, Sustainability and the Environment; Sioshansi, F.P., Ed.; Butterworth-Heinemann: Boston, MA, USA, 2011; pp. 417-442. 
5. Sartori, I.; Napolitano, A.; Voss, K. Net zero energy buildings: A consistent definition framework. Energy Build. 2012, 48, 220-232. [CrossRef]

6. Sesana, M.M.; Salvalai, G. Overview on life cycle methodologies and economic feasibility for nZEBs. Build. Environ. 2013, 67, 211-216. [CrossRef]

7. European Commission. EU Energy in Eigures_Pocketbook 2014; Publications Office of the European Union: Luxembourg, Belgium, 2014; ISBN 978-92-79-29317-7. Available online: https:/ / ec.europa.eu/energy/sites / ener/files/documents /2014_pocketbook.pdf (accessed on 27 September 2018).

8. European Commission. EU Energy in Eigures_Pocketbook 2017; Publications Office of the European Union: Luxembourg, Belgium, 2017; ISBN 978-92-79-62312-7. Available online: https: / / ec.europa.eu/transport/ sites/transport/files/pocketbook2017.pdf (accessed on 27 September 2018).

9. International Energy Agency (IEA). CO2 Emission from Fuel Combustion Highlights; Office of Management and Administration International Energy Agency: Paris, France, 2014; Available online: https:/ /www.iea. org/publications / freepublications / publication/CO2EmissionsFromFuelCombustionHighlights2014.pdf (accessed on 24 November 2015).

10. Bredenberg, A. The Damage Done in Transportation-Which Energy Source Will Lead to the Greenest Highways? ThomasNet News. 30 April 2012. Available online: http:/ / news.thomasnet.com/imt/2012/04/ 30/the-damage-done-in-transportation-which-energy-source-will-lead-to-the-greenest-highways (accessed on 2 January 2016).

11. Banjac, M.; Vasiljević, B.; Gojak, M. Low Temperature Hydronic Heating System with Radiators and Geothermal Ground Source Heat Pump. FME Trans. 2007, 35, 129-134.

12. Peterson, F. Compendium-Heating and Ventilation Systems. 1.4, Heating System: Conventional and Low Temperature [Kompendium-Uppö̈rmnings och Ventilationsteknik. 1.4, Värmesystem: Konventionella och lågtemperatur]; KTH Royal Institute of Technology: Stockholm, Sweden, 1984. (In Swedish)

13. TÜV Rheinland. Radiators and Convectors According to DIN EN 442; Technical Report, DIN CERTCO, Certification Scheme DIN-Geprüft; TÜV: Rheinland, Germany, 2008.

14. Thiemke, R. Effect of Increased Radiator Heating Capacity [Effekt af Forøgelse af Radiatorkapacitet]; Technical Report; Dansk Gasteknisk Center: Hørsholm, Denmark, 1998; ISBN 87-7795-129-8. (In Danish)

15. Danish Energy Agency. The Danish Building Code 1995-Commercial and Multi-Storey Buildings, Paragraphs 8 and 9 [Bygningsreglement for Erhvervs- og Etagebyggeri (inkl. Tillæg 1-15), 12. Installationer, 12.2 Varme-, Varmtvands- og Køleanlæg, Stk. 8. og Stk. 9.]. Available online: http:/ / bygningsreglementet. dk/br95_13_id206/0/42 (accessed on 26 December 2015). (In Danish)

16. National Board of Housing, Building and Planning (Statens Planverks Författningssamling). SBN 1980, Swedish Building Code [SBN 1980, Svensk Byggnorm, Utgåva 2], 2nd ed.; PFS 1983:2, SBN 39:32-:33; LiberTryck: Stockholm, Sweden, 1983; ISBN 91-38-07565-2. ISSN 0348-1441. (In Swedish)

17. Lindvall, N. Comparison of Two Different Adjustment Principles in a Space Heating System Consists of Hot Water Radiators (An Analysis of the Radiator Thermostatic Valves Performance and Ability to Regulate); Technical Report; Chalmers Institute of Technology (CTH), Department of Thermo and Fluid Dynamics: Gothenburg, Sweden, January 2006. (In Swedish)

18. Fahlén, P. Heat Pumps in Hydronic Heating Systems-Effective Solutions for Heating and Domestic Hot Water for Conversion of Electrically Heated Single-Family Dwellings [Värmepumpar i Vattenburna Värmesystem-Effektiva Lösningar för Värme och Varmvatten för Konvertering av Eluppvärmda Småhus]; Technical Report; Chalmers University of Technology (CTH), Building Services Engineering: Gothenburg, Sweden, 2003. (In Swedish)

19. Boerstra, A.; Veld, P.; Eijdems, H. The Health, Safety and Comfort Advantages of Low Temperature Heating Systems: A Literature Review. In Proceedings of the Healthy Buildings 2000, Espoo, Finland, 6-10 August 2000.

20. Ovchinnikov, P.; Borodinecs, A.; Strelets, K. Utilization potential of low temperature hydronic space heating systems: A comparative review. Build. Environ. 2017, 112, 88-98. [CrossRef]

21. Babiak, J.; Olesen, B.; Petras, D. Low Temperature Heating and High Temperature Cooling, Guidebook No 7; REHVA-Federation of European Heating and Air-conditioning Associations: Brussels, Belgium, 2007.

22. Fang, L.; Clausen, G.; Fanger, P.O. Impact of Temperature and Humidity on the Perception of Indoor Air Quality. Indoor Air 1998, 8, 80-90. [CrossRef] 
23. VTT Technical Research Centre of Finland. Heating and Cooling with Focus on Increased Energy Efficiency and Improved Comfort, Guidebook to IEA ECBCS Annex 37, Low Exergy Systems for Heating and Cooling of Buildings; Summary Report; VTT Research Notes 2256; VTT Technical Research Centre of Finland: Helsinki, Finland, 2004; ISBN 951-38-64-88-8.

24. Frederiksen, S.; Werner, S. District Heating and Cooling, 1st ed.; Studentlitteratur: Lund, Sweden, 2013; ISBN 978-91-44-08530-2.

25. Kazanci, O.B. Low Temperature Heating and High Temperature Cooling in Buildings. Ph.D. Thesis, Department of Civil Engineering, Technical University of Denmark (DTU), Lyngby, Denmark, 2016. Report R-356.

26. Wang, Q.; Ploskić, A.; Holmberg, S. Retrofitting with low-temperature heating to achieve energy-demand savings and thermal comfort. Energy Build. 2015, 109, 217-229. [CrossRef]

27. Gustafsson, M.; Gustafsson, M.S.; Myhren, J.A.; Bales, C.; Holmberg, S. Techno-economic analysis of energy renovation measures for a district heated multi-family house. Appl. Energy 2016, 177, 108-116. [CrossRef]

28. Ploskić, A.; Holmberg, S. Performance evaluation of radiant baseboards (skirtings) for room heating-An analytical and experimental approach. Appl. Therm. Eng. 2014, 62, 382-389. [CrossRef]

29. Purmo Thermopanel. Heat Output Calculator (Radiator Type: Purmo Compact). Available online: http: / / www.purmo.com/se/ladda-hem-filer/effektsimulering.htm (accessed on 16 May 2018). (In Swedish)

30. Purmo. Heat Output Calculator (Floor Heating). Available online: http://www.purmo.com/de/ produkte/flaechenheizung/planung-und-montage-planungsgrundlagen-waermeleistungen.htm (accessed on 21 December 2015). (In German)

31. Churchill, S. Friction Factor Equations Spans all Fluid Flow Regimes. Chem. Eng. 1977, 84, 91-102.

32. Samson. Application Notes for Valve Sizing (Sizing Examples); VDI/VDE Guideline 2173; Samson: Frankfurt, Germany, 2012.

33. Schmidt, D. Design of Low Exergy Buildings-Method and a Pre-Design Tool. Int. J. Low Energy Sustain. Build. 2004, 3, 1-47.

34. Hepbasli, A. Low exergy (LowEx) heating and cooling systems for sustainable buildings and societies. Renew. Sustain. Energy Rev. 2012, 16, 73-104. [CrossRef]

35. Rosen, M.A.; Bulucea, C.A. Using Exergy to Understand and Improve the Efficiency of Electrical Power Technologies. Entropy 2009, 11, 820-835. [CrossRef]

36. Nowacki, J.-E. Vitocalc 2010; Viessman Värmeteknik AB and KTH Royal Institute of Technology: Stockholm, Sweden, 2010. (In Swedish)

37. Fahlén, P.; Erlandsson, J. Heat Pump Water Heaters-Alternative System Solutions for Hot Water and Space Heating [Tappvattenvärmning Med Värmepump - Alternativa Systemlösningar för Varmvatten och Värme]; Technical Report; Department of Energy and Environment, Building Services Engineering, Chalmers University of Technology (CTH): Gothenburg, Sweden, June 2010; ISSN 1652-6007, R2010:03. (In Swedish)

38. SP Technical Research Institute of Sweden. Annual Field Measurements of Five Ground-Source Heat Pumps in Sjuhärad [Årsmätning på Fem Bergvärmeanläggningar i Sjuhärad]; Project from 16/11 2003 to 14/11 2004; Swedish Energy Agency: Eskilstuna, Sweden, 2005.

39. Rekstad, J.; Meir, M.; Kristoffersen, A.R. Control and energy metering in low temperature heating systems. Energy Build. 2003, 35, 281-291. [CrossRef]

40. Blomqvist, M.; Sahlin, K. Energy Statistics for One-and Two-Dwelling Buildings in 2012 [Energistatistik för Småhus 2012]; Technical Report; Swedish Energy Agency: Eskilstuna, Sweden, October 2013; ISSN 1654-7543, ES 2013:05. Available online: https:/ / www.energimyndigheten.se/globalassets/nyheter/2013/energistatistiki-smahus-2012.pdf (accessed on 22 December 2015). (In Swedish)

41. Leibundgut, H.; Baldini, L.; Sanchez, J. Energy Systems Analysis-Energy in Buildings. A Lecture on Building Systems in 6 Modules_Part 2; Institute of Technology in Architecture, Faculty of Architecture, ETH (Eidgenössische Technische Hochschule): Zürich, Switzerland, 2010.

42. Marlon, L.; Wolfgang, M.; Fish, M.N. The Evolution of Energy Efficiency Policy in Germany and the EnEV 2007. In Proceedings of the PLEA 2008-25th Conference on Passive and Low Energy Architecture, Dublin, Irland, 22-24 October 2008.

43. Uponor. Floor Heating Installation in Single Rooms (Golvvärmeinstallation i Enstaka Rum); Technical Design Guidelines; Uponor: Virsbo, Sweden, 2010; 1368S 06-01-10-SP (5:110). (In Swedish) 
44. Wilo. Basis of Pumping Technology (Pump Theory) [Grundprinciper för Pumpteknik (Pumpteori)]; Handbook; WILO Sweden AB: Växjö, Sweden, 2008. (In Swedish)

45. Thermopanel. Technical Brochure 07-2010 [Teknisk Broschyr 07-2010]; Rettig Sweden AB: Helsingborg, Sweden, 2010.

46. Lundagrossisten. Compendium in Heating, Ventiation and Sanitary, Step 2 [Utbildningskompendium, VVS-Kunskap, Steg Två]; Handbook No 6; Lundagrossisten: Stockholm, Sweden, 2014. (In Swedish)

47. Ploskić, A.; Holmberg, S. Low-temperature ventilation pre-heater in combination with conventional room heaters. Energy Build. 2013, 65, 248-259. [CrossRef]

48. Scarpa, M.; Emmi, G.; De Carli, M. Validation of a numerical model aimed at the estimation of performance of vapor compression based heat pumps. Energy Build. 2012, 47, 411-420. [CrossRef]

49. Confederation of Swedish Enterprise. Climate Compass. Available online: http://www.klimatkompassen. se/\#/348257/ (accessed on 22 December 2015).

50. Moody, L.; Princeton, N. Friction Factor for Pipe Flow. Trans. ASME 1944, 671-684.

51. Genić, S.B.; Jaćimović, B.M.; Genić, V.B. Economic optimization of pipe diameter for complete turbulence. Energy Build. 2012, 45, 335-338. [CrossRef]

52. Sarchet, B.R.; Colburn, A.P. Economic Pipe Size in the Transportation of Viscous and Nonviscous Fluids. Ind. Eng. Chem. 1940, 32, 1249-1252. [CrossRef]

53. Maivel, M.; Kurnitski, J. Heating system return temperature effect on heat pump performance. Energy Build. 2015, 94, 71-79. [CrossRef]

54. European Environment Agency. $\mathrm{CO}_{2}$ Emissions per kWh of Electricity and Heat Output. Available online: http:/ / www.eea.europa.eu/data-and-maps/figures/co2-emissions-per-kwh-of (accessed on 23 December 2015).

(C) 2018 by the authors. Licensee MDPI, Basel, Switzerland. This article is an open access article distributed under the terms and conditions of the Creative Commons Attribution (CC BY) license (http:/ / creativecommons.org/licenses/by/4.0/). 